\title{
The MILLENNIA peat cohort model: predicting past, present and future soil carbon budgets and fluxes under changing climates in peatlands
}

\author{
Andreas Heinemeyer ${ }^{1, *}$, Simon Croft ${ }^{2,6}$, Mark H. Garnett ${ }^{3}$, Emanuel Gloor ${ }^{4}$, \\ Joseph Holden ${ }^{4}$, Mark R. Lomas ${ }^{5}$, Phil Ineson ${ }^{1}$ \\ ${ }^{1}$ NERC Centre for Terrestrial Carbon Dynamics (CTCD) at the Stockholm Environment Institute (York Centre), \\ Environment Department, Grimston House, University of York (CTCD-York), York YO10 5DD, UK \\ ${ }^{2}$ Department of Mathematics, University of York, York YO10 5DD, UK \\ ${ }^{3}$ Natural Environment Research Council, Radiocarbon Facility, Rankine Avenue, East Kilbride G75 0QF, UK \\ ${ }^{4}$ School of Geography, University of Leeds, Leeds LS2 9JT, UK \\ ${ }^{5}$ CTCD and Department of Animal \& Plant Sciences, University of Sheffield, Sheffield S10 2TN, UK \\ ${ }^{6}$ Present address: c/o Andreas Heinemeyer
}

\begin{abstract}
Globally, considerable carbon (C) is stored in soils, particularly in peatlands. These stores play a potentially significant role in atmospheric $\mathrm{C}$-cycle feedbacks, and thus need to be accounted for in global models. However, present global soil models do not accurately represent peat $\mathrm{C}$-stocks and -dynamics; thus, their climate-soil C feedback predictions are questionable. A major shortcoming of current models that are based on the decomposition of soil C pools is the lack of representation of long-term (non-equilibrium) soil organic carbon (SOC) accumulation, as peat cohorts, with cohort age information. Whereas C-pool models are commonly 'spun up' to equilibrium over several hundred years using an average climate, in nature, soils actually evolve over many thousands of years with associated changes in litter amounts and quality, which affect SOC accumulation, and hence peat formation. Secondly, peat soils have a unique hydrology, and changes in the water table depth (WTD) of peat are important in regulating SOC turnover, yet current non-cohort C pool models fail to include such dynamic hydrological processes. We have developed an improved peat agecohort model called MILLENNIA, with a variable WTD driving C-dynamics during Holocene peat accumulation, allowing validation with peat age data and the testing of a realistic WTD-driven peat SOC stock response to climate-change scenarios. Model C-dynamics showed particular sensitivity to water table dynamics through precipitation and runoff, as well as to litter quality and decomposition rates. We show that predicted SOC accumulation and peat ages compare well with observations from a UK peatland site, which is currently (on average) a weak net C source with strong climate sensitivity.
\end{abstract}

KEY WORDS: Soil carbon stocks · Modelling · Peatland · Peat accumulation · Pedogenesis · Simulation modelling $\cdot$ Soil mixing $\cdot$ Litter quality

Resale or republication not permitted without written consent of the publisher

\section{INTRODUCTION}

The current human-induced increase in atmospheric $\mathrm{CO}_{2}$ and $\mathrm{CH}_{4}$ is strongly modulated by a range of terrestrial biogeochemical feedbacks coupled to climate, with the potential to amplify global warming. Quantifying biogeochemical cycles, particularly carbon, is therefore fundamental both to understanding how the Earth's climate is changing and to managing climate change. The largest store of organic carbon (C) in the biosphere is in the soil, with current estimates of around 3500 Gt (Tarnocai et al. 2009), with about onethird stored in deep $(>1 \mathrm{~m})$ peat soils of the Northern Hemisphere (NH) at mid- to high-latitudes (Gorham 
Table 1. Estimates of soil organic carbon stocks (Gt C equal to either Pg C or $\times 10^{15} \mathrm{~g}$ C) for major terrestrial biomes. The estimates in the table differ due to the respective data for soil C density (e.g. IGBP), soil depths (cm) and biome area (i.e. land cover maps). The table does not contain double accounting (e.g. peatlands are either singly counted as wetlands or boreal forests, etc.). IGBP: International Geosphere Biosphere Programme; WBGU: German Advisory Council on Global Change; ISLSCP: International Satellite Land Surface Climatology Project; IPCC: Intergovernmental Panel on Climate Change; GLCM: Global Land Cover Map.

Table after Rodeghiero et al. (2009)

\begin{tabular}{|c|c|c|c|c|c|}
\hline Biome & $\begin{array}{c}\text { IGBP }^{\mathrm{a}} \\
100 \mathrm{~cm} \\
\text { IPCC } 2001\end{array}$ & $\begin{array}{c}\text { IGBP } \\
100 \mathrm{~cm} \\
\text { GLCM } 2000^{\mathrm{b}}\end{array}$ & $\begin{array}{c}\mathrm{WBGU}^{\mathrm{c}} \\
100 \mathrm{~cm} \\
\text { IPCC } 1990\end{array}$ & $\begin{array}{c}\text { ISLSCP II }^{\mathrm{d}} \\
150 \mathrm{~cm} \\
\text { GLCM 2000 }\end{array}$ & $\begin{array}{c}\text { ISLSCP II } \\
30 \mathrm{~cm} \\
\text { GLCM } 2000^{\mathrm{b}}\end{array}$ \\
\hline \multicolumn{6}{|l|}{ Forest } \\
\hline Tropical \& subtropical & 213 & 209 & 216 & 275 & 109 \\
\hline Temperate & 153 & 97 & 100 & 131 & 43 \\
\hline Boreal & 338 & 174 & 471 & 255 & 62 \\
\hline \multicolumn{6}{|l|}{ Savanna \& grassland } \\
\hline Tropical \& subtropical & 247 & 206 & 264 & 276 & 98 \\
\hline Temperate & 176 & 171 & 295 & 236 & 80 \\
\hline Desert \& semi desert & 159 & 199 & 191 & 276 & 86 \\
\hline Tundra & 115 & 106 & 121 & 158 & 42 \\
\hline Boreal & 165 & 76 & - & 110 & 29 \\
\hline Croplands & - & 76 & 128 & 101 & 36 \\
\hline Wetlands & - & 147 & 225 & 211 & 53 \\
\hline Bare & - & 36 & - & 50 & 16 \\
\hline Total C stock & 1566 & 1497 & 2011 & 2079 & 654 \\
\hline
\end{tabular}

1991). Additionally, peat soils provide many ecosystem services such as water storage. Although peat can be much deeper than $1 \mathrm{~m}$, global (and national, see Garnett et al. 2001) C-stock estimates usually only consider the top $1 \mathrm{~m}$ of the soil and are based on rough extrapolations with large uncertainties between estimates (Table 1).

General circulation models (GCMs), which predict future climate change based on greenhouse gas level scenarios, only started including dynamic land surface variables in the last decade (Cox et al. 2000). Current predictions suggest that the land surface will cease to be a net $C$ sink by 2050 and possibly become a net source, due to soil organic carbon (SOC) losses, with considerable uncertainty regarding biotic feedbacks (IPCC 2007), the greatest uncertainty being related to the responses of SOC stocks (Friedlingstein et al. 2006). Indeed, the latest global $C$ budgets suggest this decline may have already started (Le Quéré et al. 2009). However, because of their architecture and soil hydrology (mainly developed for mineral soils), current models are unable to incorporate the key SOC processes found in peat soils. These peatland processes, on the other hand, have a potentially pivotal role in global C-cycle feedbacks (Canadell et al. 2009), due to their large C-stocks and climate vulnerability resulting from changes in water table depth (WTD) and/or temperature (Yu et al. 2003, Holden 2005).
In most of the high-latitude $\mathrm{NH}$ and northern Europe, SOC stocks accumulated during the Holocene, after the last glacial period ( 10k years ago). During this time, changes in climate have resulted in gradual variation in plant functional types (PFTs), with consequent litter quality and root input changes affecting soil organic matter (SOM) pools, SOC accumulation and decomposition rates, and WTD dynamics. In areas where climate, litter quality and limited soil mixing (i.e. incorporation of SOM into the mineral fraction) lead to surface SOM accumulation, litter and humus cohorts have developed over the mineral soil, eventually leading to peat formation with a distinctly layered ${ }^{14} \mathrm{C}$ SOC age signal (e.g. Zhang et al. 2002, Yu et al. 2003), with peat initiation in the NH high latitudes estimated at around $10 \mathrm{k}$ years ago (Johnson \& Dunham 1963, Jones \& Yu 2010). However, the future of these $\mathrm{C}$-pools and -fluxes (including $\mathrm{CH}_{4}$ ) remains unclear, especially for peat soils in high latitudes of the $\mathrm{NH}$, particularly in areas where accelerated climate change is predicted (Chimner et al. 2002). One key approach to understanding the sensitivity of these C-stocks to climate change is to explore past (i.e. peat cohort) SOC accumulation rates - equivalent to exploring the Vostok or Dome $\mathrm{C}$ ice-core records to better understand the major controls of the global C-cycle (see Yu et al. 2003). Currently model architecture, hydrology concepts and the lack of key processes in models, specifically, long- 
term decomposition of the peat cohort (mediated by litter quality) in relation to a dynamic WTD, prevent utilising this source of information.

Global model predictions of the response of soil $\mathrm{C}$ to a changing climate are questionable for several reasons. First, existing SOC turnover models divide soil C into conceptual pools with different turnover rates (e.g. Jenkinson et al. 1987, Parton et al. 1987). This semimechanistic approach is the basis of one of the most widely used SOM models, viz. CENTURY (Parton et al. 1987, Woodward et al. 1998). Secondly, soil processes in such models are largely based on century-scale concepts developed for mineral soils, excluding dynamic humus and millenia-scale peat layer development, and, thus, do not explicitly include peat soils in considerations of SOM decomposition in relation to a dynamic WTD. Consequently, the models are unlikely to adequately predict current or future global soil $\mathrm{CO}_{2}$ and $\mathrm{CH}_{4}$ fluxes and their climatic feedbacks (Jungkunst \& Fiedler 2007, Limpens et al. 2008). Notably, dynamic global vegetation models do not 'produce' realistic C-rich SOC stocks (Le Quéré et al. 2009) or peat depths (soil $\mathrm{C}$ densities are limited to $<35 \mathrm{~kg} \mathrm{~m}^{-2}$ ); global estimates of 'true' C-stocks in peat regions are much higher (up to $125 \mathrm{~kg} \mathrm{~m}^{-2}$ ) (Fig. 1), and ground surveys show even higher values (at peat depths of $>5 \mathrm{~m},>250 \mathrm{~kg} \mathrm{~m}^{-2}$ ). Thirdly, a key process responsible for humus and peat layer development is a lack in biological activity (i.e. mixing/bioturbation) by, for example, earthworms as a consequence of climate, hydrology, soil chemistry and litter quality. So far, models do not adequately reflect these pedogenetic principles and the consequent changes in the hydrological properties of soil layers resulting from altered $\mathrm{C}$ input and SOM content over time (Baumann et al. 2009). Low mixing of litter inputs with mineral layers results in mor-humus layers with low bulk density, and thus higher moisture retention, eventually leading to the formation of a mineral-free peat layer and altered hydrology, where WTD dynamics limit decomposition rates. The result is a peat column split by the WTD (Ingram 1982) into an acrotelm (above WTD and largely aerobic) versus a catotelm (below the WTD and predominantly anaerobic). Crucially, below the WTD, anaerobic decomposition of old SOM and fresh root inputs into the catotelm is slowed down considerably. Simple mineral-based C pool models do not consider the effects of peat hydrology or WTD decomposition in such low bulk density soils, and, currently, no pedogenesis-based model is available to simulate SOC dynamics ranging from mineral to peat soils (Yu et al. 2001a).

Recent global-based (e.g. Ise et al. 2008, Wania et al. 2009a,b) and site-based model developments exhibit an attempt to overcome the modelling shortfalls re-

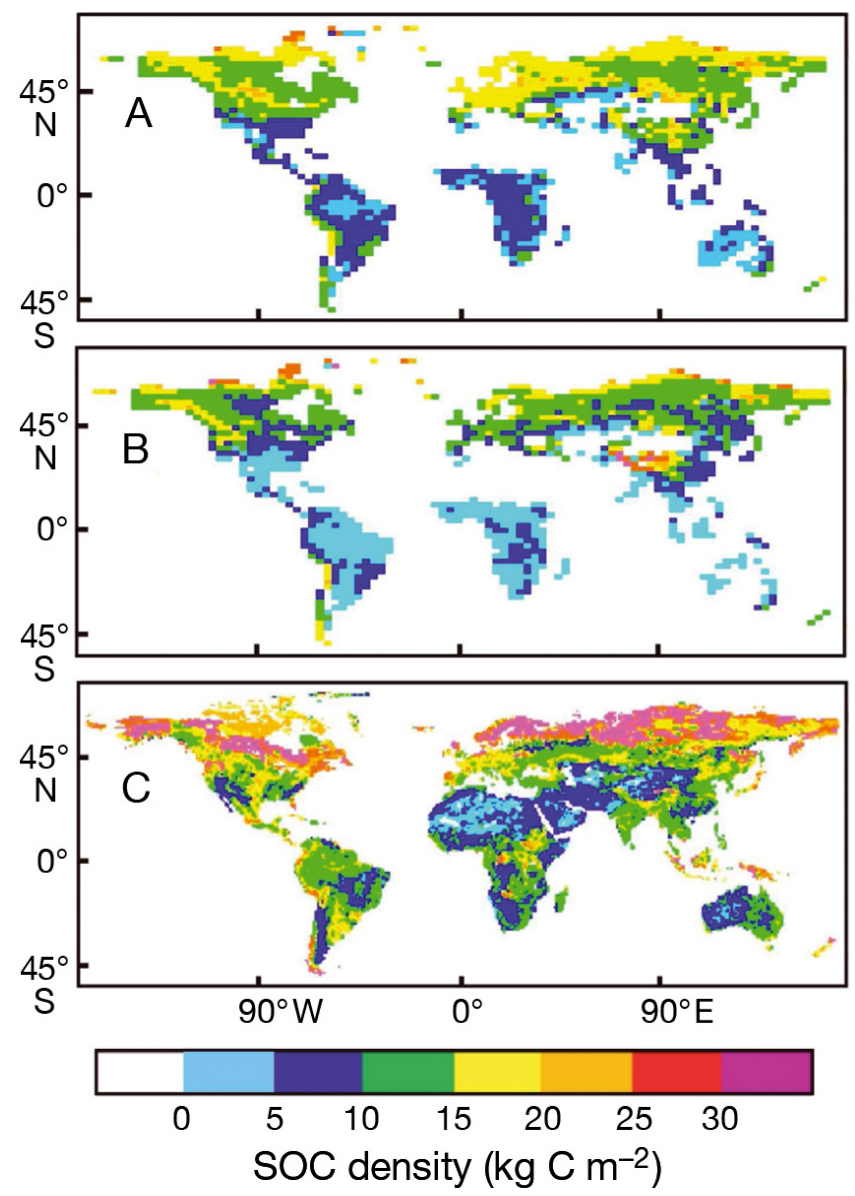

Fig. 1. Soil organic carbon (SOC) densities $\left(\mathrm{kg} \mathrm{C} \mathrm{m}^{-2}\right)$ in model outputs for the year 1860 from: (A) the Hadley Centre; (B) the RothC model versus (C) global estimates of SOC stocks based on the ISLSCP II data (0 to $150 \mathrm{~cm}$ soil depth). Panels A and B are both from Jones et al. (2004) (with kind permission from Wiley-Blackwell), and Panel C is from the ISLSCP web site (http://daac.ornl.gov/ISLSCP_II/islscpii.shtml). Note: the upper limit of SOC densities for the model is about $30 \mathrm{~kg} \mathrm{C}$ $\mathrm{m}^{-2}$ (total global SOC stock of $\sim 1000 \mathrm{Gt}$ ), whereas the global estimates (ISLSCP) show values of up to $125 \mathrm{~kg} \mathrm{C} \mathrm{m}^{-2}$ $(\sim 1500 \mathrm{Gt})$. However, the latest global SOC stock estimates (Tarnocai et al. 2009) are more than double this ( 3500 Gt)

lated to peat or humus (i.e. ForCent; W. J. Parton pers. comm.) and mixing (Jenkinson \& Coleman 2008). However, these SOC pool models are commonly 'spun up' over only a few hundred years, using constant climate (usually the long-term site average, e.g. 1960 to 1990) and vegetation to reach an 'equilibrium' SOC content by adjusting pool allocation and turnover rates; they do not consider mixing effects on mineralfree SOM cohort development. Such an approach does not take into account that soils develop over millennia, with substantial variations in climate, WTD, PFTs and litter quality affecting decomposition. It does not allow comparison with measurable SOM and $\mathrm{C}$ age-cohort 
fractions either, limiting the comparability of model results to 'real' site SOC. In fact, Luyssaert et al. (2008) recently proposed that even old growth ecosystems still accumulate SOC, although at a slow rate, calling the validity of this equilibrium method into question (Goidts et al. 2009). In summary, the current major peat-related soil $\mathrm{C}$ modelling shortfalls are:

(1) soil process representation is inadequate, specifically lacking mineral-free peat cohort layer development as a result of limited soil layer mixing;

(2) representation of mineral-free soil hydrology is unrealistic, notably lacking a dynamic peat cohort WTD regulating decomposition, and inclusion of low bulk density peat layers;

(3) soil genesis inclusion is incomplete, lacking a peat $\mathrm{C}$ age-cohort structure suitable for model validation with consideration of dynamic long-term climate effects on non-equilibrium SOC accumulation and changes in PFT and SOM quality.

Although alternative approaches to C-pool models have been developed, currently no adequate model is available to predict the future of peat SOC stock and flux changes considering all of the above shortfalls. The following section briefly outlines past model approaches taking litter quality and peat cohorts into account.

Simple litter decomposition models exist using basic, but well-established, environmental regressions to predict $\mathrm{C}$ input and the decomposition of litter/SOM. They combine actual evapotranspiration (AET)-derived net primary productivity (NPP) (Webb et al. 1978) and internal rate modifiers (e.g. litter quality) as well as external rate modifiers (e.g. AET or temperature) to predict litter decomposition rates (Minderman 1968, Meentemeyer 1978, Berg \& McClaugherty 2003). More recently, several studies have included an assessment of litter quality and decomposition along climate gradients across countries (Zhou et al. 2008) or even continents (Gholz et al. 2000); inclusion of these data in simple 3-pool litter decomposition models, incorporating internal and external modifiers, have shown promising results (Adair et al. 2008). Some recent models have even had multiple soil horizons (Wallman et al. 2006).

Litter decomposition models have also been applied to simulate $\mathrm{C}$ accumulation in peatlands since the early work of Clymo (1984); these use a litter cohort approach with increasing complexity, as summarized by Yu et al. (2001a). Occasionally this approach has considered climate response surfaces to determine peatland PFTs (Gignac et al. 1991, Bauer et al. 2003) but crucially, has never considered a long-term change in climate and thus variable hydrology (i.e. WTD) and NPP, mainly due to the lack of past climate data since the end of the last glaciation (i.e. for the UK, $10 \mathrm{k}$ years ago). Furthermore, these models did not consider the long-term consequences of dynamic WTD-driven PFT changes with litter quality and root input effects on SOC accumulation, cohort age and decomposition $\mathrm{C}$ fluxes.

Our model builds on components from the above literature to develop a dynamic peat cohort model considering Holocene SOC accumulation and specifically addressing dynamic litter (including root) inputs and hydrology (including WTD). In the following we: (1) present an improved peat cohort model structure (MILLENNIA), addressing realistic millenial time scale peat cohort SOC build-up taking dynamic WTD and PFT changes into consideration and providing a basis for further humus and peat cohort model developments; (2) show model validation with UK field data, including peat cohort age profiles; (3) predict the climate sensitivity and future evolution of a UK upland peatland on annual to century time-scales; and (4) present a basic model sensitivity analysis.

Whereas the first half introduces the test site and the MILLENNIA peat cohort model with validation, the second half applies the model to address the research hypotheses given below ( $\mathrm{H} 1$ to $\mathrm{H} 5$; related to peat accumulation) in order to determine which model outputs are affected by the inclusion of currently absent processes and to what extent.

(H1) A realistic Holocene climate spin-up with variable PFT alters peat accumulation rates and final SOC stocks significantly as compared to assuming a constant climate.

(H2) Root litter NPP input is crucial for realistic peat SOC stock and age predictions.

(H3) Currently, UK peatlands are in a near-equilibrium SOC state, mainly due to the time since peat initiation and a relatively stable recent climate.

(H4) The near-equilibrium SOC state of peat is vulnerable to predicted high-latitude $\mathrm{NH}$ climate-change scenarios.

(H5) Within the predicted range of climate-change scenarios, precipitation is more important in affecting SOC stocks than temperature.

\section{METHODS}

\subsection{Site description and data availability}

\subsubsection{Moor House, Upper Teesdale}

For model testing we chose the Moor House National Nature Reserve (NNR), a site of the UK Environmental Change Network (ECN). Long-term meteorological data, as well as detailed data on soil properties (e.g. bulk density) and hydrological characteristics (WTD), are available for the site. The Moor House NNR is an upland 
area $\left(\sim 75 \mathrm{~km}^{2}\right)$ located in the northern Pennines, UK (ranging from about 290 to $848 \mathrm{~m}$ above sea level). The climate can be classified as sub-arctic-oceanic, with an average long-term mean annual temperature (MAT) and precipitation (MAP) of about $5.3^{\circ} \mathrm{C}$ and $2000 \mathrm{~mm}$, respectively. However, MAT has been shown to have recently increased to $5.8^{\circ} \mathrm{C}$ (Holden \& Rose 2010). The site is one of the largest areas of blanket bog in England, and is a World Biosphere Reserve. Extensive peat formation began in the late boreal ( $9 \mathrm{k}$ years ago), as bog communities began to replace a birch forest, the macroremains of which are commonly found at the base of the peat (Johnson \& Dunham 1963).

We focused on a square kilometre around the ECN meteorological station (NY757328; 54 $68^{\prime} \mathrm{N}, 2^{\circ} 37^{\prime} \mathrm{W}$ ), a site of histosol (commonly known as peat), supporting vegetation (mainly Calluna vulgaris L. [Hull] and Eriophorum sp. with some Sphagnum sp.-dominated moss patches), classified as a Calluna vulgaris-Eriophorum blanket mire. Typically the site has a pH of around 4.3 and a high mean annual WTD $(\sim 5 \mathrm{~cm})$.

\subsubsection{Moor House soil carbon stocks}

Garnett (1998) studied the blanket bog across the Moor House area and provided detailed data on total peat depth in relation to aspect, slope and vegetation type, and compared estimates with the national database (Garnett et al. 2001). However, this comparison was limited to $1 \mathrm{~m}$ soil depth, although blanket peat can occur much deeper than this (Garnett 1998), with the mean depth of intact peat at around 50 to $250 \mathrm{~cm}$, depending on aspect and slope. Using bulk density site data (Garnett 1998), this equates to SOC stocks of about 25 to $125 \mathrm{~kg} \mathrm{C} \mathrm{m}^{-2}$; in comparison, a $1 \mathrm{~m}$ depth limitation would only equate to around 25 to $45 \mathrm{~kg} \mathrm{C} \mathrm{m}^{-2}$.

\subsection{The MILLENNIA peatland cohort model concept}

The model presented here (called MILLENNIA) functions in annual time-step intervals on a square meter plot-level and is a modified peat decomposition model (PDM) based on litter cohorts and AET-derived NPP inputs (shoot and root). Unlike previous models (e.g. Frolking et al. 2001, Bauer et al. 2003), MILLENNIA includes simple climate-driven WTD dynamics regulating decomposition in 2 peat layers, the acrotelm and catotelm (Ingram 1982; see Fig. 2A). Decomposition rates are modified by external (e.g. temperature and oxygen availability) and internal (e.g. lignin to hemicellulose and soluble $\mathrm{C}$ ratio) factors. Crucially, peat accumulation and depth can change in both directions (i.e. C gain or loss). The MILLENNIA PDM 'grows' total peat depth during a specified Holocene period (i.e. over the past $\sim 10 \mathrm{k}$ years) as annual cohorts, tracking individual cohorts (over depth) and total peat column age (mass-weighted average of all cohorts). Notably, this long-term buildup of total C-stocks with inherent $\mathrm{C}$ age information and variable NPP and root inputs (i.e. suitable for model versus field data validation) is not included in the above-mentioned or other available peat models such as the CASA model (Potter 1997). Moreover, WTD and PFTs are dynamic in our PDM (Fig. 2),
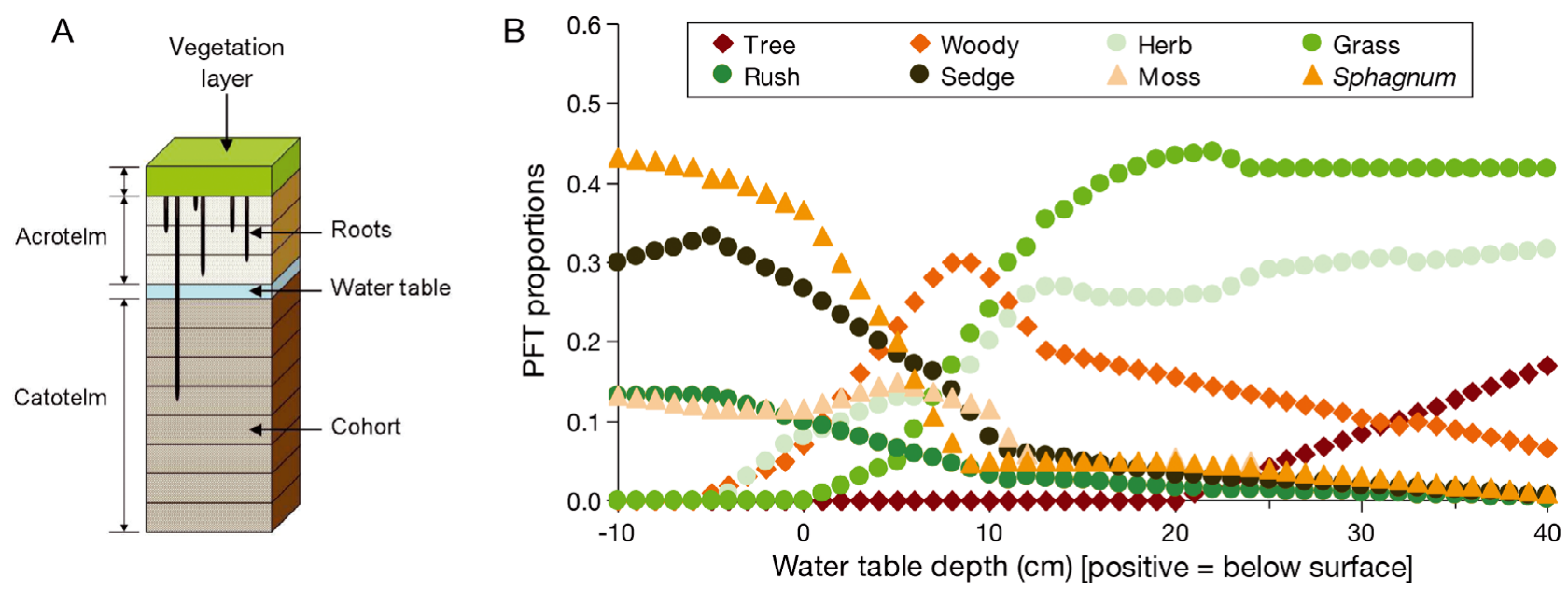

Fig. 2. MILLENNIA peat model. (A) Modelled peat column with water table depth (WTD) dividing peat cohort layers plus rooting zone and thus litter input into acrotelm versus catotelm cohorts (note: bedrock is not shown, and the surface $10 \mathrm{~cm}$ is considered a vegetation layer, including a mat of moss, Sphagnum and root, allowing WTD to be above the peat surface). (B) Estimated plant functional types (PFT) as proportions of net primary productivity based on mean annual WTD 
reflecting changes in climate (e.g. time and aspect) and runoff (e.g. rainfall intensity and slope) that affect both decomposition and methane fluxes. Annual WTD (although monthly WTD can be calculated, see Clark et al. 2010, this Special) is used to estimate decomposition and gas exchange, due to the constraint in the applied annual empirical relationship for litter mass loss (e.g. Jenny et al. 1949, Clymo et al. 1998). In the following we present some of the most fundamental model structures.

\subsection{Model input data and process description}

\subsubsection{Holocene climate and potential evapotranspiration}

Reconstructed Holocene climate data are necessary to realistically model variable past water table, NPP and decomposition and, thus, peat accumulation. In general, it is difficult to obtain local information on Holocene climate, particularly on an annual scale, as is needed for our PDM. However, such data are available for other regions across the globe at similar latitudes, mainly based on pollen records (e.g. Xu et al. 2009). These data show rapid warming and increased precipitation around 10k years ago and subsequently some variability in mean climate parameters, with certain periods of significant change (e.g. cold versus warm and dry versus wet). We used (1) a combination of 2 North American (NA) datasets (Gajewski et al. 2004, Bunbury et al. 2006), but adjusted the onset of major change to $10 \mathrm{k}$ years ago to reflect UK conditions; (2) a reconstruction based on Oak Ridge National Laboratory (ORNL) information (www.esd. ornl.gov/projects/qen/nercEUROPE.html) using records for China (Xu et al. 2009) as an indication of the magnitude of changes; and (3) a constant present climate $\left(4.75^{\circ} \mathrm{C}\right.$ and $\left.1922 \mathrm{~mm}\right)$ based on elevation-corrected MetOffice (gap free) records from 1931 to 2005 (Clark et al. 2010, this Special). Crucially, such data include MAT and MAP, which can be used to derive AET using a simple equation (Turc 1954); although more sophisticated equations exist, the necessary input data are currently not available for the Holocene, although future projects might deliver much better Holocene climate reconstructions (e.g. www.bridge.bris.ac.uk/ projects). Comparison of AET predictions for a similar Welsh site with actual latent heat fluxes (from eddy covariance) were in good agreement (not shown); in general, eddy covariance stations (e.g. CarboEurope) could provide a good check on the validity of this or other AET models. We also had access to site ECN meteorological station data, but these included several data gaps.

\subsubsection{Water table and runoff}

The MILLENNIA PDM assumes that the WTD is the result of allogenic factors (external) (Clymo 1984) and for simplicity ignores more complex compaction changes with depth. It reflects a simple hydrology concept and is calculated as the balance of previous WTDs and new water input, the latter being calculated as the difference in precipitation (PPT), AET (Turc 1954) and runoff, including assumptions on how much pore space is available for infiltration based on peat depth above the WTD. Runoff is calculated annually or monthly depending on the antecedent WTD, the PPT and the slope, the latter reflecting a sine function increase in runoff between a $0^{\circ}$ and $90^{\circ}$ angle. If the antecedent WTD is shallow, then a large proportion of the annual PPT runs off due to the high hydrological conductivity of the peat near-surface (Evans et al. 1999). Conversely, if the WTD is deep, a larger proportion of the PPT is retained. At Moor House a roughly exponential empirical relationship has been suggested, with values ranging from $0.9 \times \mathrm{PPT}$ at a WTD of $0 \mathrm{~cm}$ to $0.1 \times$ PPT at a WTD of $70 \mathrm{~cm}$ (Holden et al. 2007). We adjusted the following equation to enable simulation of the mean site WTDs (ECN data) at monthly and annual time scales:

$$
\text { Runoff }=\left[1-\left(0.9-0.7325 \mathrm{e}^{(-0.01 \mathrm{WTD})} \cos (2 \pi)\right] \mathrm{PPT}\right.
$$

\subsubsection{Plant functional types and net primary productivity}

Vegetation cover is determined by a response surface approach (e.g. Gignac et al. 1991). We used a Canadian wetland database of plant species coverage (area) versus WTD (Zoltai et al. 2000) comprising several sites and collected over a $5 \mathrm{yr}$ period. We then grouped the information consistently with the PFTs observed in UK blanket peatlands and created a reference table for coverage proportions of 8 major and representative, but in many ways contrasting, PFTs (trees, shrubs [i.e. 'woody' in Fig. 2], herbs, Sphagnum moss, other bryophytes, grasses, rushes and sedges). These proportions were adjusted (Fig. 2) to reflect coverage (biomass) based on expert knowledge and information on UK peatland areas (Forrest 1971). So far, the model assumes WTD as the prime determinant of PFT coverage and excludes temperature effects. NPP (in $\mathrm{g}$ dry matter $\mathrm{m}^{-2} \mathrm{yr}^{-1}$ ) is calculated from the global Thornthwaite Memorial equation (Lieth \& Box 1972) in relation to potential evapotranspiration (PET), and subsequently converted into $\mathrm{g} \mathrm{C} \mathrm{m}^{-2} \mathrm{yr}^{-1}$ using a conversion factor of 0.5 (Heal \& Smith 1978) such that:

$$
\mathrm{NPP}=0.5\left[3000\left(1-\mathrm{e}^{-0.0009695(\mathrm{PET}-20)}\right)\right]
$$


Notably, this relationship has been supported in the UK in comparison to site NPP values by Garnett (1998). There is large uncertainty as to how to distribute NPP above- and below-ground (Kosykh et al. 2008). The assumed proportions that each PFT contributes to above- versus below-ground NPP are PFT specific (below-ground: 2/5 for shrub and trees versus 2/3 for other vascular plants) and the depth of root NPP allocation is either a uniform or exponential distribution (see Table 2), with maximum rooting dependent on the WTD (Bauer 2004). Root NPP is mostly allocated above the WTD in an exponential way, i.e. with most NPP at the soil surface and a PFT-specific parameter determining that only $20 \%$ of the root NPP is deposited below the WTD. However, several centimetres of shrub and tree root NPP are included in the aboveground NPP pool, as they are commonly observed in heather peatlands above the peat surface in the moss layer, explaining the larger above-ground NPP proportion. Rushes and sedges are assumed to grow roots to a depth of 50 and $60 \mathrm{~cm}$, respectively, when WTD is $<0 \mathrm{~cm}$ and trees have a maximum rooting depth of $2 \mathrm{~m}$. If the maximum rooting depth exceeds the peat column, then inputs are assigned to the 'penetrable' bedrock layer.

\subsubsection{Litter input, quality, decomposition and C-fluxes}

Litter input is assumed to be equal to annual NPP, but is composed of different litter qualities based on the PFTs (see Table 2). Above-ground (leaf) litter is deposited at the surface, whereas root litter is distributed throughout the profile according to the root NPP distribution (see Section 2.3.3). Litter is divided into 3 chemical fractions: soluble, holocellulose and lignin, as proposed by Wallman et al. (2006), based on estimated PFT chemical compositions (Jones \& Gore 1978, Bauer 2004) and their mass fractions added to the cohort. However, bryophytes and Sphagnum show altered chemical composition with WTD according to Bauer (2004). These litter chemical inputs are added respectively to the total mass remaining in each cohort at the end of the previous year, leading to 'proportional bins' of each chemical fraction (Bauer 2004) with unique decomposition rates $\left(\mathrm{yr}^{-1}\right)$. Basically, soluble material decaying rapidly $(0.719)$ in the initial stages, holocellulose slower (0.469) and lignin very slowly (0.060); these rates reflect a discounted static $\mathrm{N}$-effect included by Bauer (2004) of 0.575, 0.375 and $0.06 \mathrm{yr}^{-1}$, respectively, to allow a variable $\mathrm{N}$-effect due to dynamic PFT changes. These decay rates are modified from their initial baseline value at the surface, where decomposition is fastest, first by internal and then by external ratemodifier factors, and WTD regulates the magnitude of

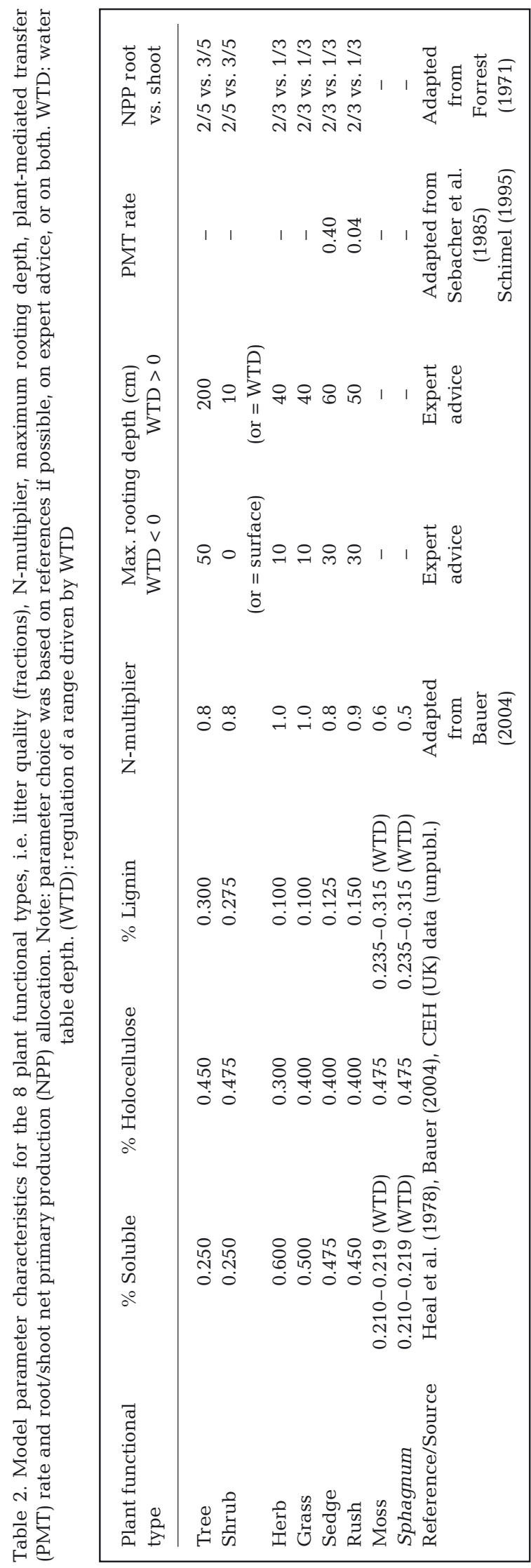


these effects. Decomposition rates are applied to each chemical fraction separately following the same basic structure as outlined by Clymo et al. (1998).

Internal rate modifiers. The chemical fraction decay approach used here was first introduced by Berg (1986), but see also Berg \& Ekbohm (1991) and Berg \& McClaugherty (2003), based on litter bag studies. Firstly, the litter $\mathrm{N}$-content affects initial decomposition rates of the soluble and holocellulose fractions, but not lignin (see Bauer 2004), and as our model includes root litter inputs, the decomposability of the lignin pool is calculated as the proportion of lignin remaining compared with the total amount added (see Frolking et al. 2001). Secondly, the ligno-cellulose quotient is more important in later stages, found to have an asymptotic decay limit, which is calculated for each cohort as a weighted average of the litter types. In order to accommodate the addition of litter inputs each year, this limit is averaged annually from existing and new litter proportions of the total mass. The internal decay rates in a cohort are calculated based on their relationship to the decay rate of lignin. If the ligno-cellulose quotient is greater than the asymptotic limit of this quotient, then, for each cohort in year $i$, the internal decay rate (INT) of these chemical fractions [ $j=$ (soluble and holocellulose)] are calculated as follows:

$\alpha_{\mathrm{INT}, j, i}=\alpha_{\mathrm{INT}, \mathrm{Lig}, i}+\left(\alpha_{\mathrm{N}, j, i}-\alpha_{\mathrm{INT}, \mathrm{Lig}, i}\right) \frac{Q_{i}-Q_{C}}{Q_{0}-Q_{c}}$

where $\alpha_{\mathrm{N}, j, i}$ is the $\mathrm{N}$-adjusted surface decay rate for each chemical fraction, $Q_{i}$ is the ligno-cellulose quotient of the cohort in year $i$ and $Q_{\mathrm{c}}$ is the asymptotic limit of the ligno-cellulose quotient. $Q_{0}$ is the lignocellulose quotient of fresh surface litter, and $\alpha_{\text {INT,Lig }}$ is the internal lignin decay rate. If the limit of the lignocellulose quotient has been reached, then the rates of both holocellulose and soluble fractions equals that of lignin.

External rate modifiers. We consider $\mathrm{pH}$, temperature and oxygen availability. Temperature and oxygen availability both positively affect decomposition, with lower values inhibiting decay. Soil temperature decreases with depth, with a sudden drop below the water table. This is incorporated into the model by applying a simple multiplier (f[Temp]) to the decay rate, leaving it unchanged at the surface and decreasing exponentially by $20 \%$ of the rate at the peat base (Frolking et al. 2001). For terrain studies we also consider slope and aspect effects on temperature based on considerations of Barry \& Chorley (2003). Oxygen availability is determined by the position of the water table, assuming fully oxic conditions and unchanged decay rates above the WTD. Below the WTD (catotelm), decay is anaerobic and slowed down by a multiplier (fOx) corresponding to changes in the WTD (oxic:anoxic ratio), ranging from 1 above the WTD to 0.0625 at a depth of $10 \mathrm{~cm}$ below the water table, with a linearly decreasing relationship at depths in the intervening region according to Bauer (2004) and Frolking et al. (2001). The final decay rates of each chemical fraction $j=$ (soluble, holocellulose, lignin) in a cohort are calculated as follows based on the INT decay rates:

$$
\alpha_{j, i}=\alpha_{\mathrm{INT}, j, i} \times \mathrm{f}(\mathrm{Ox}) \times \mathrm{f}(\mathrm{Temp})
$$

The model assumes that the annual $\mathrm{C}$ mass loss through decomposition is converted to either $\mathrm{CO}_{2}$ or $\mathrm{CH}_{4}$, the proportions of which are determined by the cohort position in relation to the WTD, with $\mathrm{CO}_{2}$ the product of aerobic decomposition in the acrotelm and $\mathrm{CH}_{4}$ the product of anaerobic decomposition in the catotelm (after Clymo 1984). We assume that all gases produced are emitted over the year, but $\mathrm{CH}_{4}$ diffusing through the acrotelm is potentially oxidized, depending on the acrotelm dry mass (using bulk density and dry matter conversion of modelled $\mathrm{g} C$ units, see below), at a rate of $1.021 \times 10^{-3} \mathrm{~mol} \mathrm{~g}^{-1} \mathrm{yr}^{-1}$ (Watson et al. 1997), or is emitted directly via plant-mediated transport (PMT) through aerenchyma as proposed by Potter (1997). We chose PMT values of $4 \%$ for rushes versus $40 \%$ for sedges based on Sebacher et al. (1985) and Schimel (1995), respectively. All other PFT PMT values were ' 0 '.

\subsubsection{Long-term peat development}

Each year the masses of the peat cohorts change depending on total NPP litter inputs versus total decomposition as outlined in Section 2.3.4. The total height of the peat column is based on the peat column bulk density (BD) profile (in g dry organic matter $\mathrm{Cm}^{-3}$ ), which becomes denser with depth. The model applies a sigmoidal curve ranging from 0.05 at the surface to 0.10 at the base (compaction effect) of the peat with an inflection point at the WTD line, comparable to the findings of Garnett (1998) and Heal \& Smith (1978). However, we also allow for peat expansion immediately under the WTD 'BD(below)' line (the 'sponge' effect):

$$
\begin{aligned}
& \mathrm{BD}(\text { above })=0.05+0.07 /\left(1+\mathrm{e}^{(-\mathrm{WTD} / 10+1)}\right) \\
& \mathrm{BD}(\text { below })=1-0.2 \mathrm{e}^{(\mathrm{WTD}+1 / 10)} \mathrm{BD}(\text { above })
\end{aligned}
$$

From these equations the total peat height can be calculated by summing all peat layers, which is also crucial for determining the WTD level and thus acrotelm versus catotelm depth, mass and decomposition rates. Total $\mathrm{C}$-stock per square meter is derived by multiplication of the dry organic matter mass by a factor of 0.50 (see above; Heal \& Smith 1978). Finally, we 
formulated an erosion equation (used for the terrain study only), based on total organic carbon (TOC) export in relation to runoff (Billett et al. 2004), but allowed for higher MAP infiltration and thus TOC export (including dissolved organic carbon [DOC] export) with increasing WTD based on considerations of Holden $\&$ Burt (2002); however, no erosion occurs at WTD $>0$ :

$$
\text { Erosion TOC }=4 \text { WTD }\left(1-\mathrm{e}^{(- \text {Runoff/100) }}\right)
$$

\subsection{Model sensitivity analysis}

\subsubsection{Climate-related parameters}

In order to investigate model sensitivity to climate, we altered the range of MAT and MAP over a $200 \mathrm{yr}$ period (from 2000 to 2200) after a 10k yr spin-up using the ORNL climate data. We adjusted MAT by $+2{ }^{\circ} \mathrm{C}$ and $+4{ }^{\circ} \mathrm{C}$ individually and in combination with MAP by $\pm 25 \%$; these changes capture the expected range of climate change for the UK and reflect the likely uncertainty in the MAP scenarios.

\subsubsection{Plant-related parameters}

The plant parameter sensitivity analysis focused on root to shoot NPP litter allocation, rooting depth, litter quality and decomposition rates. Default values (see Sections 2.3.3 \& 2.3.4 and Table 2) were changed by $\pm 10, \pm 20$ and $\pm 40 \%$ over the entire $10 \mathrm{k}$ yr ORNL spinup period. All vegetation type parameters/equations were equally affected and, for litter quality, reflected an increase/decrease in the lignin fraction, allocated equally to soluble and hemicellulose fractions.

\subsubsection{Soil-related parameters}

Soil parameter sensitivity investigated BD, runoff and the oxic:anoxic ratio. Default values (see Sections 2.3.2 to 2.3.5 and Table 2) were changed by \pm 10 , \pm 20 and $\pm 40 \%$ over the entire 10k yr ORNL spin-up period apart from runoff, which was changed by \pm 2.5 , \pm 5 and $\pm 10 \%$ (otherwise resulting in extreme WTD values).

\section{RESULTS}

\subsection{Holocene climate and water table depth}

The 2 reconstructed variable climates showed only limited differences and followed the same trend of initially increasing MAT and MAP (Fig. 3A). However, although the NA climate showed fairly stable conditions $3 \mathrm{k}$ yr after peat initiation, the peaks and troughs were much more pronounced in the ORNL data (relying on interpretation of the ORNL information) and showed several longer periods of either very warm and moist ( $4.5 \mathrm{k}$ to $5.5 \mathrm{k} \mathrm{yr}$ ), warm and moist (1.0k to $2.0 \mathrm{k} \mathrm{yr}$ ), warm and dry (5.5k to $6.5 \mathrm{k} \mathrm{yr}), \mathrm{cool}$ and moist (3.5k to $4.0 \mathrm{k} \& 7.0 \mathrm{k}$ to $8.0 \mathrm{k} \mathrm{yr}$ ), or cool and dry (9.0k to $9.5 \mathrm{k} \mathrm{yr})$ periods (Fig. 3). Neither dataset included finer interannual variation. For example, the variation in the present-day MetOffice data (adjusted for elevation bias) showed the same ranges in MAT and MAP seen over the entire Holocene period. Consequently, WTDs (Fig. 3B) using those climate data did not vary much, and until 1931 showed mean WTDs of $7.1 \pm 0.0,6.7 \pm$ 1.2 and $6.3 \pm 2.3 \mathrm{~cm}$ for constant, NA and ORNL climates, respectively. From 1995 to 2005 (Fig. 3B, inset), the mean WTD of $7.6 \pm 8.6 \mathrm{~cm}$ was in good agreement with the observed contemporary mean WTD of the ECN site $(4.8 \pm 2.7 \mathrm{~cm})$, which was improved further by using ECN station climate data $(5.4 \pm 6.0 \mathrm{~cm})$; annual WTD values were very similar between modelled and observed scenarios (Fig. 3B, inset).

\subsection{Blanket peat carbon accumulation during the Holocene}

Differences in final peat accumulation derived through various reconstructed Holocene climates were minor (Fig. 3C) and reflected the small differences in the actual annual climate and WTD through time, yet, overall, faster accumulation was seen in both variable cases compared to the case of constant climate (Fig. 3A,B). The ORNL dataset, with the largest variation in mean annual climate, only showed about $5 \mathrm{~kg} \mathrm{C}$ $\mathrm{m}^{-2}$ higher total $\mathrm{C}$ accumulation $\left(135 \mathrm{~kg} \mathrm{C} \mathrm{m}^{-2}\right.$ ) than the constant climate (Fig. 3C), similar to reported site measurements of around $125 \mathrm{~kg} \mathrm{C} \mathrm{m}{ }^{-2}$ (Garnett unpubl. data). The ORNL run also revealed peat accumulation phases of 3 distinctly faster periods $(1.0 \mathrm{k}$ to $2.0 \mathrm{k}, 3.5 \mathrm{k}$ to $4.0 \mathrm{k}$ and $7.0 \mathrm{k}$ to $8.0 \mathrm{k} \mathrm{yr}$ ) after peat initiation under very moist conditions, and 3 slower ones under very warm and moist $(4.5 \mathrm{k}$ to $5.5 \mathrm{k}$ yr) or dry (5.5k to $6.5 \mathrm{k}$ and $9.0 \mathrm{k}$ to $9.5 \mathrm{k} \mathrm{yr}$ ) conditions. Overall average Holocene peat accumulation rates were $13.6 \mathrm{~g}$ $\mathrm{C} \mathrm{m}^{-2} \mathrm{yr}^{-1}$ or $0.025 \mathrm{~cm} \mathrm{yr}^{-1}$, similar to values reported by $\mathrm{Yu}$ et al. (2001b). Limited differences in peat accumulation were reflected in very similar NPP rates over time (Fig. 3C), which ranged between 380 and $520 \mathrm{~g} \mathrm{C}$ $\mathrm{m}^{-2} \mathrm{yr}^{-1}$. However, there were 2 distinct periods at around $4 \mathrm{k}$ and $7 \mathrm{k}$ yr of several hundred years of increased peat growth (Fig. 3C), which coincided with periods of climatic change (Fig. 3A) resulting in higher WTD (Fig. 3B). 

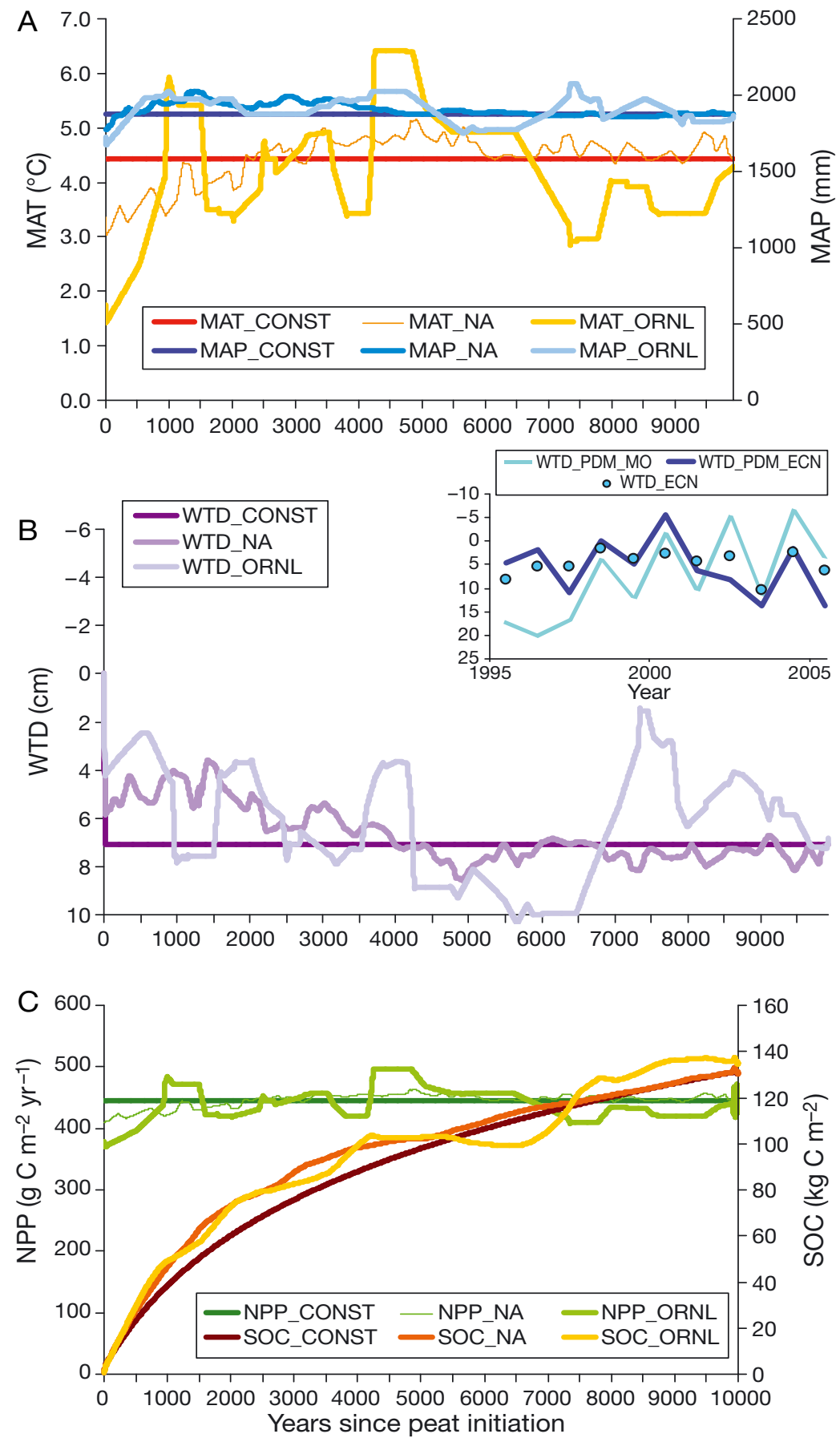

Fig. 3. (A) The 3 reconstructed Holocene climate datasets (MAT and MAP: mean annual air temperature and precipitation, respectively) for Moor House National Nature Reserve (either based on constant [CONST] present [1931 to 2005] MetOffice, North American [NA], or European [ORNL] data). (B) Water table depth (WTD; negative numbers reflect standing water within the $10 \mathrm{~cm}$ of surface moss/root layer) for each climate run; the model runs for 1995 to 2005 (inset) are also shown, using either the MetOffice (MO) climate data (WTD_PDM_MO) or the Environmental Change Network (ECN) climate data (WTD_PDM_ECN) and the ECN WTD site observation data (WTD_ECN; circles). PDM: MILLENIA peat development model. (C) MILLENNIA peat cohort model predictions of net primary productivity (NPP) and soil organic carbon (SOC) accumulation during the Holocene, corresponding to either a constant mean annual average (MetOffice data from 1931 to 2005) or the 2 reconstructed Holocene climate datasets

\subsection{Predicted carbon accumulation rates, peat profile age and soil carbon fluxes}

Predictions of Holocene carbon accumulation rates ranged between 0 and $100 \mathrm{~g} \mathrm{C} \mathrm{yr}^{-1}$ (Fig. 4), with a mean $( \pm \mathrm{SD})$ of $13 \pm 11$ versus $15 \pm 18 \mathrm{~g} \mathrm{C}$ $\mathrm{yr}^{-1}$, for constant versus variable climate, respectively. The peat cohort age profiles (Fig. 4) initially showed a sharp age increase with increasing cohort depth until around $150 \mathrm{~cm}$ depth, increasing more slowly thereafter to a total age of $10 \mathrm{k} \mathrm{yr}$, which is in agreement with radiocarbon-dated site data (Garnett 1998). The total peat column age showed a similar depthage relationship, and the average peat column age after 10k yr was $3 \mathrm{k}$ yr. In both cases, excluding root litter inputs resulted in slightly less peat accumulation $(\sim 30 \mathrm{~cm})$ and greater cohort and column age per equivalent depth for peat depths $>50 \mathrm{~cm}$.

More recent real climate variations (1931 to 2005) using ECN and MetOffice site climate records (see Fig. 5) showed that higher WTD (positive values) corresponded to lower $\mathrm{CH}_{4}$ (mean of $\sim 5$, max. of $28 \mathrm{~mol} \mathrm{yr}^{-1}$ ), but greater $\mathrm{CO}_{2}$ (mean of $\sim 30$, max. of $54 \mathrm{~mol} \mathrm{yr}^{-1}$ ) decomposition fluxes (Fig. 5A) and a lower net $\mathrm{C}$ budget (mean \pm SD accumulation of $-15 \pm 148 \mathrm{~g} \mathrm{C}$

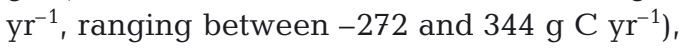
corresponding to peat depth increments during this period of approximately $-0.5 \mathrm{~cm} \mathrm{yr}^{-1}$.

\subsection{Estimated blanket peat carbon budget at Moor House, considering terrain}

Based on DEM GIS data (not shown) we grouped pixels into ranges of slope $\left(0-5^{\circ}\right.$, $\left.5-10^{\circ}, 10-25^{\circ}\right)$ and aspect $\left(90^{\circ}\right)$, and the model runs for these combinations showed a considerable reduction in peat depth and SOC stocks with increasing slope, but less so for southwest-facing aspects (Table 3). The predicted values and decreasing trends compared well with an unpublished survey conducted by Garnett (Table 3). However, SOC stocks were greater and increasing slope reduced SOC stocks ( $\sim 60$ vs. $\left.\sim 100 \mathrm{~kg} \mathrm{~m}^{-2}\right)$ and peat depth ( $\sim 100$ vs. $\sim 170 \mathrm{~cm}$ ) less (when not considering erosion) for model data than for site data. Including erosion, SOC stocks were very similar to observed data, although the initial decline in SOC and peat depth with slope and southerly or westerly aspect was less pronounced. 


\subsection{Predicted future peat carbon accumulation and fluxes}

Simple future climate scenarios (imposed from the year 2000 over $200 \mathrm{yr}$ ) altered SOC stocks and C-fluxes significantly, the least under a $2^{\circ} \mathrm{C}$ temperature increase and the most under the warmest and driest scenario (Fig. 6). Overall, a $2^{\circ} \mathrm{C}$ higher MAT with increased MAP increased SOC stocks by about $5 \mathrm{~kg} \mathrm{C}$ $\mathrm{m}^{-2}$, but less so with a $4^{\circ} \mathrm{C}$ rise over $200 \mathrm{yr}$ (Fig. 6A). Correspondingly, soil decomposition fluxes as $\mathrm{CO}_{2}$ increased while $\mathrm{CH}_{4}$ decreased slightly, but more so in the $+4^{\circ} \mathrm{C}$ scenarios, corresponding to slightly lower WTD (Fig. 6A); $\mathrm{CH}_{4}$ fluxes only increased under the wetter and less warm scenario, which was also the only scenario with a rise in WTD. The greatest effect was observed for the $+4^{\circ} \mathrm{C}$ MAT and $-25 \%$ MAP scenario, in which the mean SOC continually declined nearly $15 \mathrm{~kg} \mathrm{C} \mathrm{m}{ }^{-2}$ over $200 \mathrm{yr}$, corresponding to a sharp decline in WTD to around $25 \mathrm{~cm}$ and resulting in Cfluxes of up to $50 \mathrm{~mol} \mathrm{~m}^{-2} \mathrm{yr}^{-1}$ for $\mathrm{CO}_{2}$ and no $\mathrm{CH}_{4}$ fluxes.

\subsection{Sensitivity analysis of the MILLENNIA PDM}

Climate sensitivity analysis was restricted only to changes in increased MAT, with or without a slight reduction or increase in MAP (Fig. 6), and revealed MAP to be the most important factor, which was consistent with expectations, especially with increasing MAT, which led to decreasing WTD and considerable SOC losses over 200 yr (see Section 3.5).
Plant parameter analysis (Fig. 7) revealed minimal effects on SOC and peat depth (Fig. 7A) or on C-fluxes (Fig. 7B) by changing root versus shoot litter inputs or by altering rooting depth; however, better or worse litter quality (i.e. worse meaning greater lignin content) SOC and peat depth, respectively, in comparison to the default value model run. Accordingly, faster or slower decomposition rates decreased or increased SOC and peat depth, respectively. Changing litter quality or decomposition rates by $40 \%$ had a similar effect and halved or doubled SOC stocks and peat depth, respectively. The greatest effect on $\mathrm{CO}_{2}$ and $\mathrm{CH}_{4}$ fluxes was observed when litter quality or decomposition rates were altered, whereby slower decomposition led to larger $\mathrm{CH}_{4}$ but lower $\mathrm{CO}_{2}$ fluxes (Fig. 7B).

Changing soil parameters (Fig. 8) revealed BD and runoff to be the most sensitive parameters. Although decreasing BD by $40 \%$ doubled SOC and peat depth, increasing runoff by $10 \%$ led to an almost 6 -fold decrease in SOC and peat depth, with significant changes in $\mathrm{CO}_{2}$ and $\mathrm{CH}_{4}$ fluxes (i.e. due to corresponding WTD changes).

\section{DISCUSSION}

\subsection{Holocene climate model spin-up and water table}

The most significant factors in long-term peat accumulation were time and MAP, determining WTD, decomposition and litter quality and distribution through changes in PFTs. However, although short spin-up times are known to limit realistic peat accumu-
Fig. 4. MILLENNIA peat cohort model predictions of peat depth versus peat cohort (brown lines) and total peat column (orange lines) age profiles over $10 \mathrm{k}$ yr using variable reconstructed Holocene climate (ORNL, see Fig. 3), either allocating net primary productivity to both root and shoot litter (solid lines), or only to shoot litter (broken lines), preventing additional carbon input into deeper (older) peat cohorts due to root growth. Model-predicted annual $\mathrm{C}$ increments (black line; with root litter inputs only) with an average of $15 \mathrm{~g} \mathrm{C} \mathrm{yr}^{-1}$ and site radiocarbon peat profile data (Garnett 1998) are also shown (red diamonds)

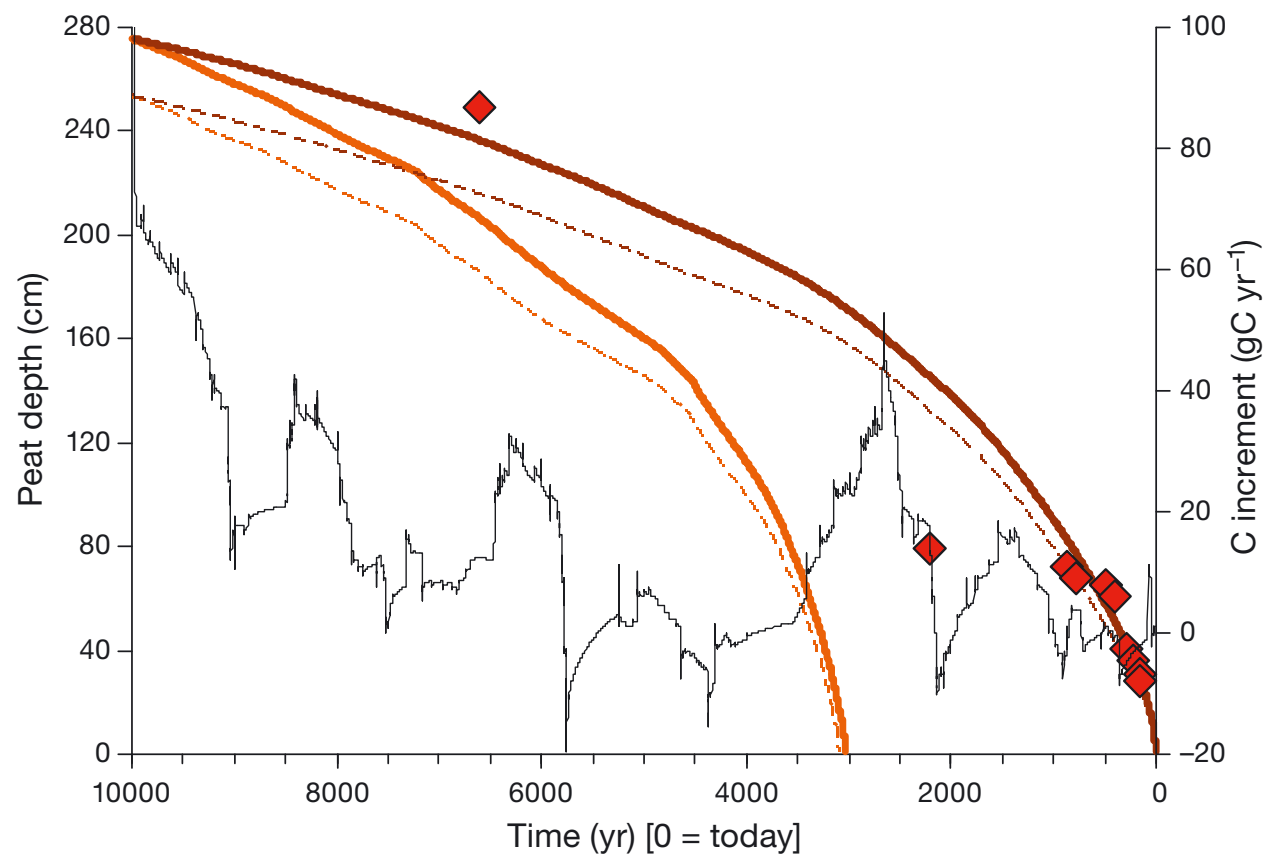



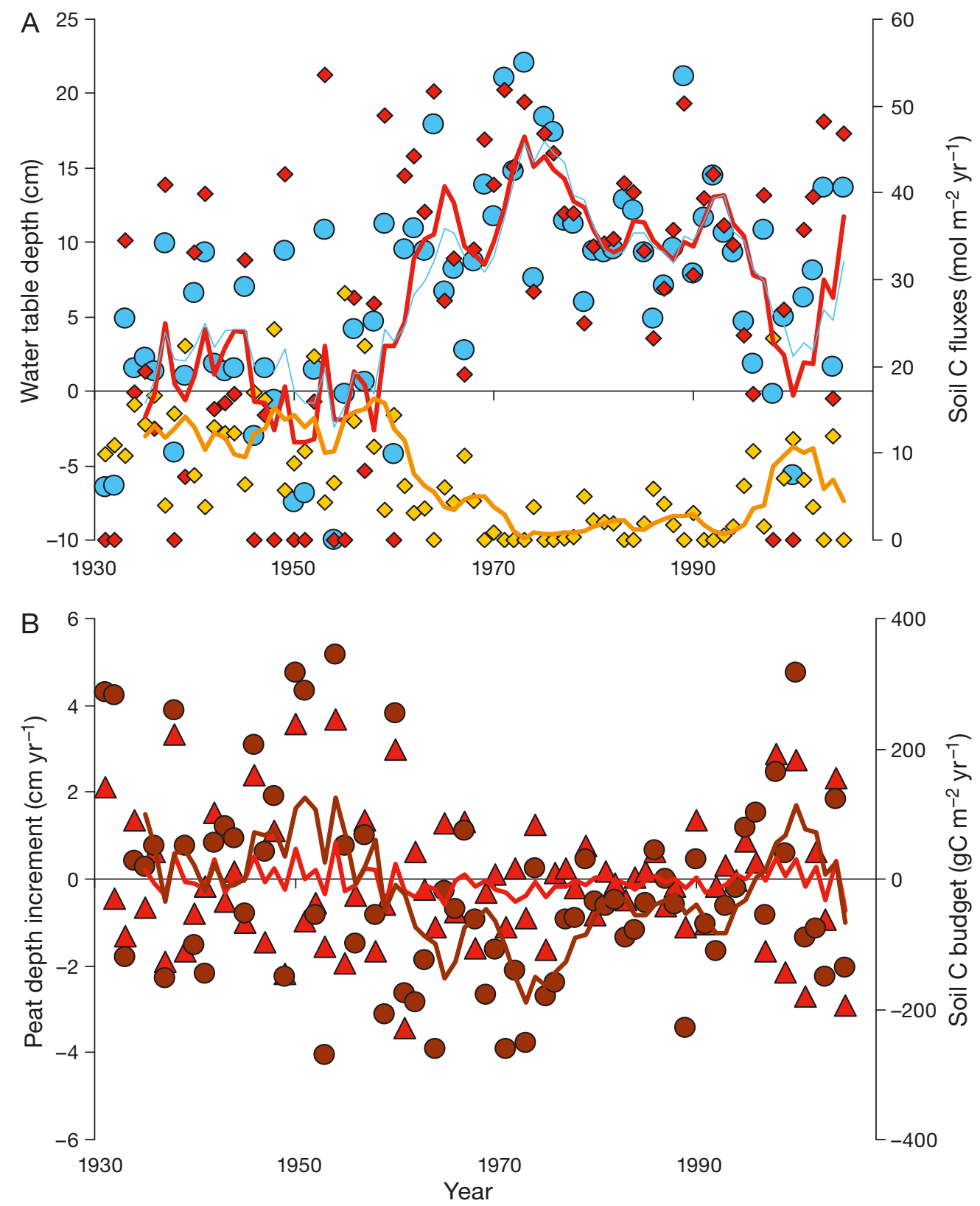

Fig. 5. MILLENNIA peat cohort model predictions showing annual outputs from the individual long-term annual climate data for the period from 1931 to 2005 (MetOffice data; equivalent to Years 9925 to 10000 after peat initiation) for the Moor House ECN site using a variable reconstructed 10k yr Holocene climate model spin-up (ORNL). (A) Annual water table depth (WTD; blue circles) and soil decomposition C-fluxes as $\mathrm{CO}_{2}$ (red diamonds) and $\mathrm{CH}_{4}$ (yellow diamonds). (B) The peat depth increments (red triangles) and soil C-budget (brown circles), with a positive number indicating a net gain. The 5 yr running averages are indicated in the corresponding line colours

lation (Wania et al. 2009b), contrary to H1, a constant Holocene climate did not significantly alter the final total $\mathrm{C}$ accumulation over $10 \mathrm{k}$ yr compared to a variable climate (Fig. 3C), but did alter $\mathrm{C}$ accumulation rates (Fig. 4) and SOM quality ('proportional bins') in each cohort due to PFTs and, consequently, litter quality input (not shown). Changing MAT had relatively little impact on Holocene WTD (Fig. 3B), but affected
NPP (Fig. 3C). However, very high MAT limited the MAP effect, particularly during a wet period around 4.5 to $5.5 \mathrm{k}$ years ago. One reason might be the overall very high MAP at the site. Notably, the variation in Holocene climate (Fig. 3A) by $\sim 3^{\circ} \mathrm{C}$ MAT and $\sim 300 \mathrm{~mm}$ MAP resulted in only small changes in final peat accumulation over time (Fig. 3C), similar to other UK upland peat data (Tallis 1991). This indicates that in 
Table 3. GIS-based model predictions of soil organic carbon (SOC) stocks and peat depth based on selected combinations of slope $\left(0\right.$ to $5^{\circ}, 5$ to $10^{\circ}, 10$ to $\left.25^{\circ}\right)$, aspect $\left.(0[\mathrm{~N}]], 90[\mathrm{E}], 270[\mathrm{~W}], 180[\mathrm{~S}]\right)$, and elevation (all 500 to $700 \mathrm{~m}$ ) for the Moor House National Nature Reserve site. Model predictions used the Oak Ridge National Laboratory reconstructed Holocene climate data and represent the mean value for elevation and slope range per aspect; values include SOC export (erosion and DOC), whereas those values in italics do not. As a comparison, mean 'real' site SOC and peat depth are provided for the same ranges (with SD provided if available, but mostly based only on 1 to 3 peat cores per average) based on unpublished survey data (M. H. Garnett) in the Moor House area. (-) No data

\begin{tabular}{|c|c|c|c|c|c|c|c|}
\hline \multicolumn{2}{|c|}{ Terrain information } & \multicolumn{3}{|c|}{$\longrightarrow \operatorname{SOC}\left(\mathrm{kg} \mathrm{C} \mathrm{m}^{-2}\right) \longrightarrow$} & \multicolumn{3}{|c|}{$\longrightarrow$ Peat depth $(\mathrm{cm})$} \\
\hline \multirow{2}{*}{$\frac{\text { Slope }\left({ }^{\circ}\right)}{0-5}$} & \multirow{2}{*}{$\frac{\text { Aspect }}{\mathrm{N}}$} & \multicolumn{2}{|c|}{ Model predictions } & \multirow{2}{*}{$\begin{array}{c}\text { Site measurement } \\
124.57 \pm 12.17\end{array}$} & \multicolumn{2}{|c|}{ Model prediction } & \multirow{2}{*}{$\begin{array}{c}\text { Site measurement } \\
231.75 \pm 21.31\end{array}$} \\
\hline & & 152.24 & 170.90 & & 275.52 & 308.35 & \\
\hline $0-5$ & E & 150.10 & 170.70 & $95.69 \pm 22.45$ & 272.23 & 308.08 & $207.86 \pm 35.67$ \\
\hline $0-5$ & $\mathrm{~W}$ & 148.23 & 170.60 & - & 268.66 & 307.92 & - \\
\hline $0-5$ & $\mathrm{~S}$ & 145.74 & 169.93 & 66.77 & 264.27 & 306.73 & $151.00 \pm-.-$ \\
\hline $5-10$ & $\mathrm{~N}$ & 148.91 & 165.90 & $94.20 \pm 23.78$ & 269.89 & 299.79 & $175.50 \pm 30.41$ \\
\hline $5-10$ & E & 142.69 & 164.81 & $81.27 \pm 32.05$ & 258.94 & 297.77 & $164.67 \pm 65.45$ \\
\hline $5-10$ & W & 134.00 & 162.15 & $45.80 \pm 6.85$ & 243.56 & 293.00 & $58.75 \pm 9.91$ \\
\hline $5-10$ & $\mathrm{~S}$ & 124.62 & 158.22 & $43.82 \pm 5.17$ & 227.03 & 286.01 & $76.67 \pm 13.80$ \\
\hline $10-25$ & $\mathrm{~N}$ & 110.00 & 135.06 & $81.49 \pm 41.75$ & 201.44 & 245.50 & $151.00 \pm 65.05$ \\
\hline $10-25$ & E & 87.90 & 125.69 & $71.98 \pm 24.64$ & 162.41 & 228.80 & $150.67 \pm 38.89$ \\
\hline $10-25$ & W & 53.08 & 112.73 & - & 101.15 & 205.86 & - \\
\hline $10-25$ & $\mathrm{~S}$ & 24.45 & 103.97 & $29.40 \pm 21.22$ & 43.36 & 190.31 & $65.50 \pm 57.28$ \\
\hline
\end{tabular}

the UK, although climate variability was important during peat growth stages, it was not important longterm, also shown by a near-linear relationship between peat depth and initiation time (Tallis 1991), which can be linked to peat buffering WTD alterations due to precipitation changes as shown in the fairly constant WTDs (Fig. 3B). Modelled peat accumulation using the ORNL data showed significant periods of either faster or slower accumulation rates (Fig. 3B), which could be linked to distinct climatic periods (Fig. 3A), with higher rates in wet and slower rates in dry periods. Interestingly, the 2 most rapid accumulation periods after peat initiation $(\sim 3.5 \mathrm{k}$ and $\sim 6.5 \mathrm{k}$ yr $)$ were similar to those observed at a Canadian site (see Fig. 2 in Chimner et al. 2002) and those reported by $\mathrm{Yu}$ et al. (2003). Notably, similar Holocene climate and PFT changes for NA and Europe have been suggested (Gajewski et al. 2006). Nevertheless, improved Holocene climate reconstructions of MAT and MAP are needed for a more realistic model spin-up, leading to realistic long-term, dynamic and field-comparable $\mathrm{C}$ accumulation. Particularly, capturing the onset of peat initiation during the warmer and wetter period across the UK around $9 \mathrm{k}$ years ago (Tallis 1991) is important; however, see Section 4.2 for potential underestimation of ${ }^{14} \mathrm{C}$ SOC and peat age estimations.

The model captured WTD fluctuations during the validation period (1995 to 2005) very well, yet showed noticeably lower WTD compared to the ECN site data for 1997 and 2005 (Fig. 3B, inset), years of incomplete ECN records for either MAP or WTD data, respectively. However, monthly WTD is known to fall well below $20 \mathrm{~cm}$ during dry periods (Evans et al. 1999,
Ward et al. 2007). Importantly, for future model validation work, past site WTD could be reconstructed using testate amoeba for WTD and wetness reconstructions (e.g. Charman \& Hendon 2000).

\subsection{Peat $\mathrm{C}$ accumulation and comparison to site measurements}

The MILLENNIA PDM builds up SOC stocks and peat depths (Table 3 ) and Holocene peat accumulation rates (Fig. 4) comparable to measured profiles for Moor House NNR, purely based on climate without a pre-set SOC, peat depth, or WTD (unlike most other models). According to Garnett (1998), average peat depth based on 3 cores is $231.75 \pm 21.31 \mathrm{~cm}$ (see Table 3 ) and mean annual Holocene $\mathrm{C}$ increment estimates are $27 \mathrm{~g} \mathrm{C}$ $\mathrm{yr}^{-1}$, ranging between 5 and $100 \mathrm{~g} \mathrm{C} \mathrm{yr}^{-1}$, values very similar to our model predictions. Moreover, the final modelled period (1931 to 2005) showed mean NPP rates of $447 \pm 27 \mathrm{~g} \mathrm{C} \mathrm{m}^{-2} \mathrm{yr}^{-1}$; although slightly higher than those reported by Garnett (1998), field data are known to underestimate below-ground (root) NPP. Overall model performance was confirmed by site ${ }^{14} \mathrm{C}$ age profiles (Fig. 4). However, contamination is an issue in the routine ${ }^{14} \mathrm{C}$ analysis of bulk peat samples of deeper cohort ages due either to more recent $\mathrm{C}$ input through roots or vertical $\mathrm{C}$ movement with water or microbes, although we showed the root effect to be small (Fig. 4). However, using plant macrofossils or even more sophisticated ${ }^{14} \mathrm{C}$ aliphatic hydrocarbon analysis (Huang et al. 1999) can potentially overcome such ${ }^{14} \mathrm{C}$-age contamination issues with depth, as it 

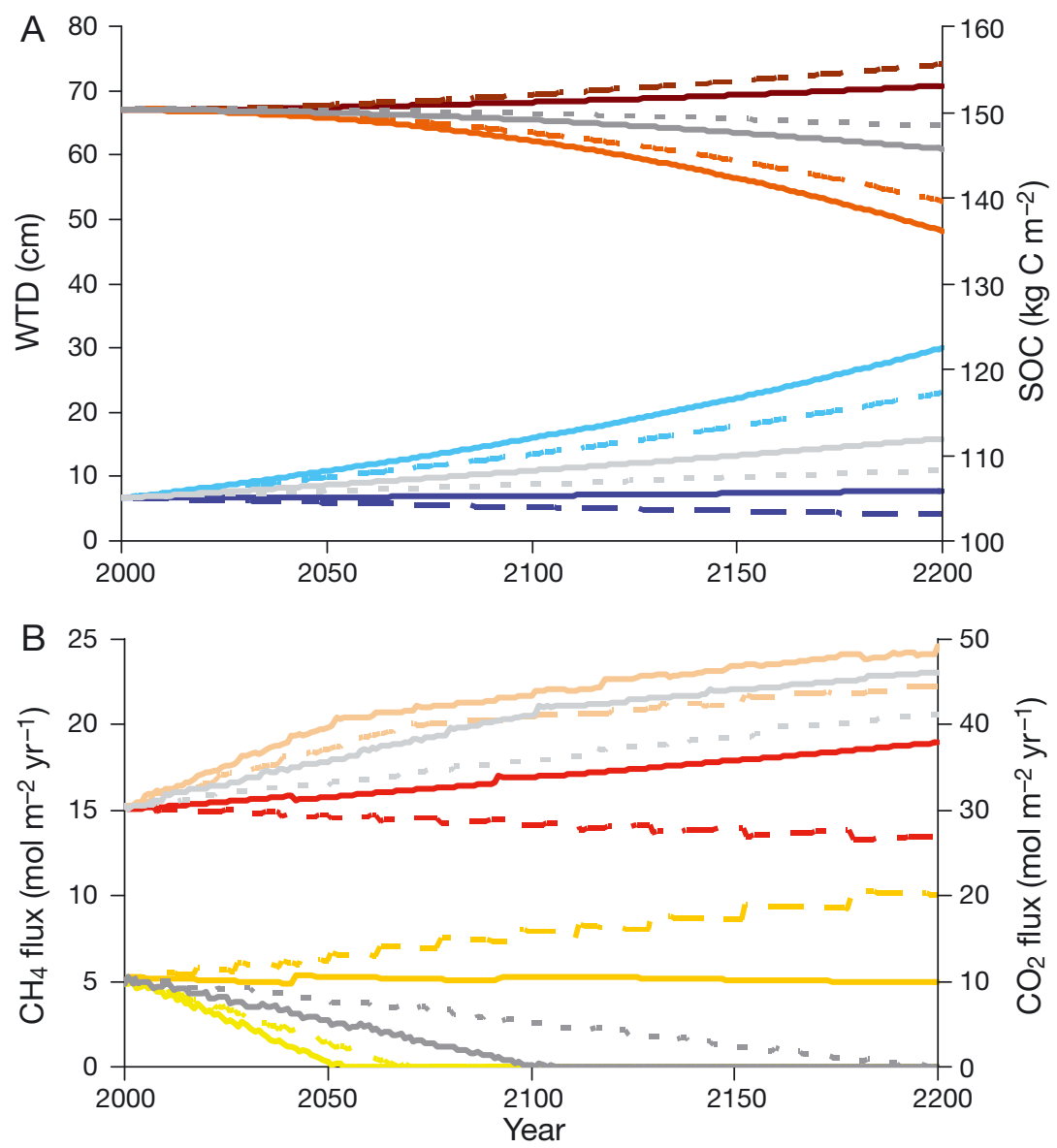

Fig. 6. MILLENNIA climate sensitivity analysis with peat cohort model predictions using MetOffice climate data at the Moor House ECN weather station site for a model spin-up and 3 future climate scenarios (from 2000) based on likely target assumptions of linear changes in annual mean temperature $(+2$ or $+4^{\circ} \mathrm{C}$ ) and additional change in precipitation $( \pm 25 \% \mathrm{~mm})$ by 2200 ; dark versus light colours indicate precipitation increase versus decrease, respectively, and broken versus solid lines indicate lower versus higher temperature, respectively. (A) Water table depth (WTD; blue) and soil organic carbon (SOC) stocks (brown) and the corresponding results for the 2 temperature-only scenarios $+2^{\circ} \mathrm{C}$ (broken line) or $+4^{\circ} \mathrm{C}$ (solid line) for WTD (light grey) and SOC (dark grey). (B) Soil decomposition $\mathrm{CH}_{4}$ (yellow) and $\mathrm{CO}_{2}$ (red) fluxes and the corresponding fluxes for the 2 temperature-only scenarios $+2^{\circ} \mathrm{C}$ (broken line) or $+4^{\circ} \mathrm{C}$ (solid line) for $\mathrm{CO}_{2}$ (light grey) and $\mathrm{CH}_{4}$ (dark grey)

refers to litter fall age, free from fresh root and water soluble C contamination (Bol et al. 1999).

\section{3. $\mathrm{C}$ turnover, root litter and $\mathrm{C}$ fluxes}

Surface decay rates were important factors determining eventual peat height and mass accumulation, with even smaller changes in these rates resulting in a disproportionate change in peat accumulation, which is particularly important when WTD drops due to, for example, slope (Table 3). However, little is known about surface litter turnover in peatlands, as most litter decomposition studies have been based on mineral soils. Further, in accordance with $\mathrm{H} 2$, the inclusion of root inputs significantly altered peat accumulation and column predictions (Fig. 4), justifying the need for more data on root distribution and NPP inputs in these systems. Root litter directly adds $\mathrm{C}$ to cohorts below the surface layer (Fig. 2) and also below the WTD line, which consequently spends less time in the acrotelm, leading to more peat accumulation, although the magnitude of this increase was less than expected. The addition of fresh root litter into a model cohort causes a noticeable increase in the overall decomposability of a cohort due to changes in the 'proportional bins'. Further, PMT of $\mathrm{CH}_{4}$ via roots is determined by rooting depth, allowing bypassing of the natural oxidation potential of the acrotelm. Nonetheless, model predictions of C-fluxes (Fig. 5) for both $\mathrm{CO}_{2}\left(\sim 35 \mathrm{~mol} \mathrm{~m}^{-2} \mathrm{yr}^{-1}\right)$ and $\mathrm{CH}_{4}\left(\sim 5 \mathrm{~mol} \mathrm{~m}^{-2} \mathrm{yr}^{-1}\right)$ were in the range reported for the site $\left(\sim 5 \mathrm{~mol} \mathrm{~m}^{-2} \mathrm{yr}^{-1}\right.$; Worrall et al. 2003, Ward et al. 2007) and for the northern peatlands ( $\sim 5$ to $10 \mathrm{~mol} \mathrm{~m}^{-2} \mathrm{yr}^{-1}$; Laine et al. 2007). Yet hardly any data are available to compare model predictions of $\mathrm{CO}_{2}$-fluxes from decomposition only (e.g. Kelly et al. 1997); firstly, because field $\mathrm{CO}_{2}$ data nearly always include root-derived respiration, whilst SOM models only predict $\mathrm{C}$-fluxes from decomposition, and, secondly, because field $\mathrm{CO}_{2}$ measurements are often taken on vegetation-free plots, not including (a mostly unknown) $\mathrm{CH}_{4}$ PMT transport. Ideally, this model would be tested at sites offering all those validation data, but so far only insufficient data are available on root distribution, decomposition rates and PMT, making further research urgent.

An important advantage of the cohort, and thus SOC age-profile, information including fresh root inputs, is the ability to derive a ${ }^{14} \mathrm{C}$-SOC cohort age and subsequently ${ }^{14} \mathrm{C}$-fluxes. This enables field validation of $\mathrm{C}$ accumulation, as shown here, and, potentially, could relate isotopic signature to soil formation (Bol et al. 1999) and to soil priming and PMT of peat decomposition C-fluxes (Garnett \& Hardie 2009, Hardie et al. 2009). Yet, the available ${ }^{14} \mathrm{C}$ peat profile data focus mostly on the top peat layers (Fig. 4). We have, thus, 

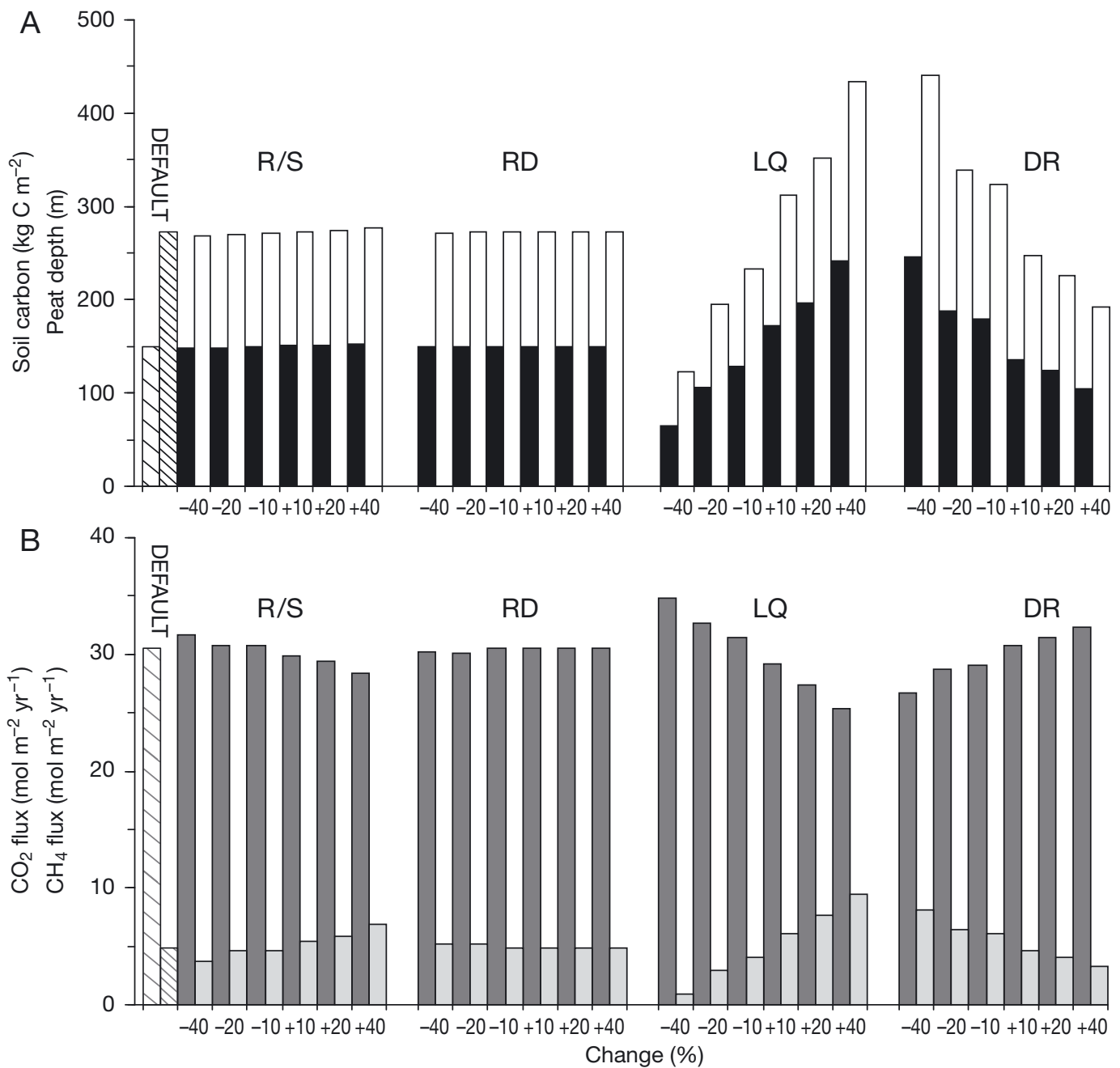

Fig. 7. Input plant parameter sensitivity analysis of the MILLENNIA model during the Holocene (10k yr) spin-up. Parameters investigated were root versus shoot net primary productivity litter allocation (R/S), rooting depth (RD), litter quality (LQ) and decomposition rates (DR); default values (see 'Sections 2.3.3 and 2.3.4' and Table 2) were changed by $\pm 10, \pm 20$ and $\pm 40 \%$ over the entire period. All vegetation type parameters/equations were equally affected, and for litter quality $+/-$ reflected an increase/ decrease in the lignin fraction, allocated equally to soluble and hemicellulose fractions. Model outputs for the final year compared to the default scenario (i.e. no change) for: (A) soil carbon (black) and peat depth (white) and (B) soil decomposition fluxes as $\mathrm{CO}_{2}$ (dark grey) and $\mathrm{CH}_{4}$ (light grey) are shown

shown the advantage of building-up realistic peat depths and dynamic SOC cohort layers: (1) to include decomposition C-fluxes from deep peat layers (important for total $\mathrm{CH}_{4}$ and $\mathrm{CO}_{2}$ emissions) and (2) to allow dynamic long-term feedbacks between peat depth and hydrology (WTD changes).

\subsection{Peat $\mathrm{C}$ budget and terrain effects}

In agreement with H3, current peat growth has reached a plateau (Fig. 3C), and, using recent (1931 to 2005) climate data (Fig. 5), the model even indicated a small net $C$ budget loss of about $-15 \pm 148$ (SD) $\mathrm{g} \mathrm{C} \mathrm{yr}^{-1}$, with a noticeable decline since the 1960s. The overall

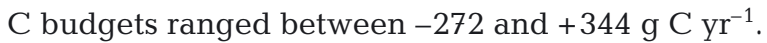

Using a digital elevation model (DEM) for $1 \mathrm{~km}^{2}$ around the Moor House ECN meteorological station site, we ran the model for a representative range of slopes (affecting runoff and MAT) and aspects (affecting MAT), which showed negative correlations of slope with both peat depth and SOC stocks (Table 3). Interestingly, the SOC stocks and observed peat depths were very similar to field observations (M. H. Garnett unpubl. data), albeit only when including erosion through runoff linked to WTD changes. Erosion (including DOC export) led to around 10 to $50 \mathrm{~g} \mathrm{C} \mathrm{m}^{-2}$ $\mathrm{yr}^{-1}$ SOC loss, comparable to the results of Billett et al. (2004). However, our model does not include erosion effects through wind or frost. Moreover, we did not consider any run-on effects or topography changes with peat growth; ideally the bedrock topography 

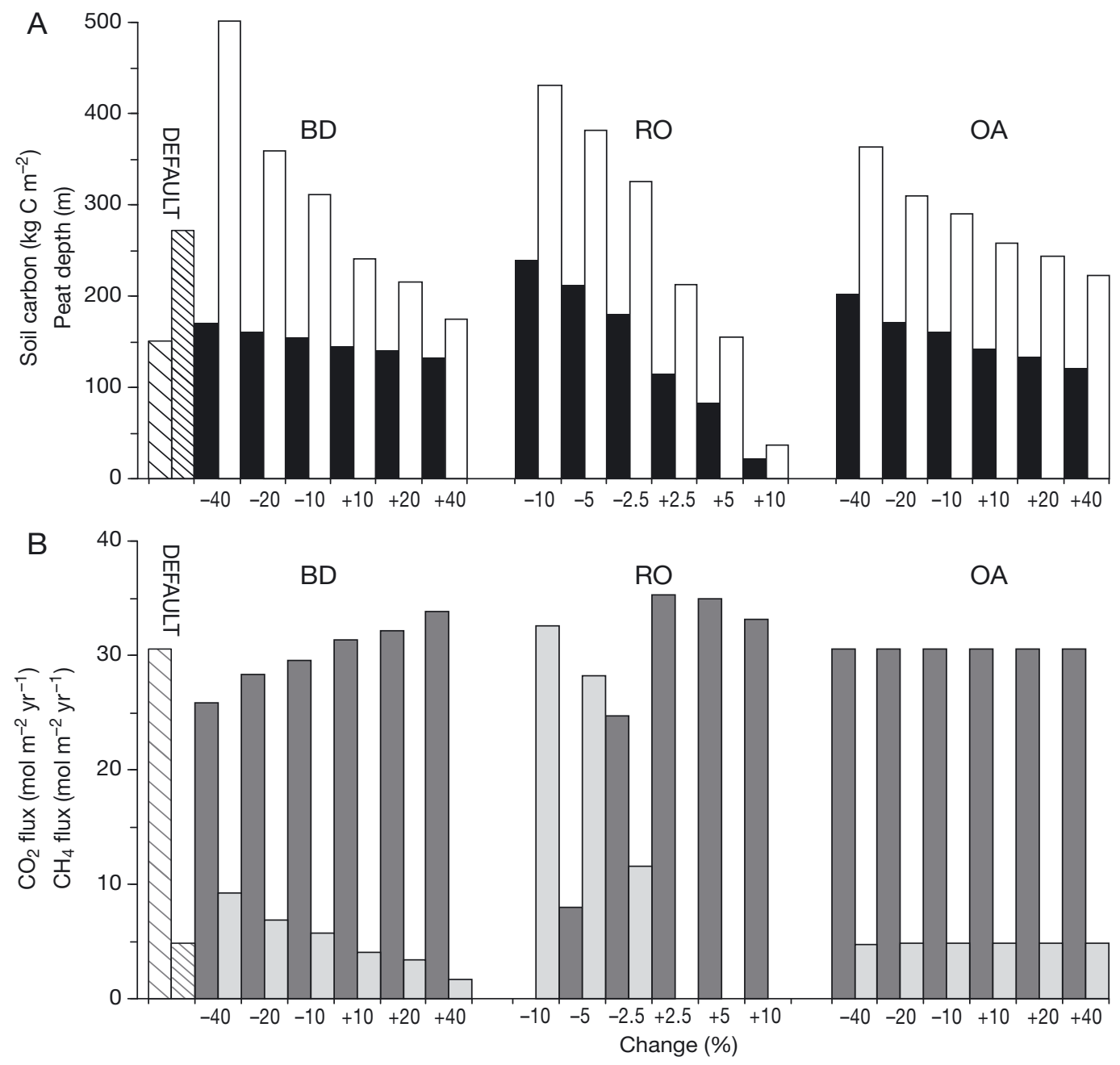

Fig. 8. Input soil parameter sensitivity analysis of the MILENNIA model during the Holocene (10k yr) spin-up. Parameters investigated were bulk density (BD), runoff (RO) and the oxic:anoxic ratio (OA); default values (see Sections 2.3.2 to 2.3.5 and Table 2 ) were changed by $\pm 10, \pm 20$ and $\pm 40 \%$ over the entire period apart from runoff, which was changed by $\pm 2.5, \pm 5$ and $\pm 10 \%$. Model outputs for the final year compared to the default scenario (i.e. no change) for: (A) soil carbon (black) and peat depth (grey) and (B) soil decomposition fluxes as $\mathrm{CO}_{2}$ (dark grey) and $\mathrm{CH}_{4}$ (light grey)

slope would be used to drive the model, as surface topography changes with peat growth. The use of groundpenetrating radar might prove useful in achieving this (Holden et al. 2002).

\subsection{Future climate scenarios and peat $\mathrm{C}$ dynamics}

Future climate scenarios (Fig. 6) showed climate vulnerability of current peat SOC stocks as proposed in $\mathrm{H} 4$; predicted small $\mathrm{C}$ gains under warmer and wetter conditions (due to increased NPP) versus considerable $\mathrm{C}$ loss in warmer and drier climates over $200 \mathrm{yr}$, with WTD determining the direction of $\mathrm{C}$-stock and C-flux (i.e. $\mathrm{CH}_{4}$ ) changes (cf. Frolking et al. 2001). However, Frolking et al. (2001) did not use a variable past climate or dynamic WTDs (i.e. no hydrology model); therefore, they could not test for realistic model sensitivity to climate and WTD (i.e. including PFT and NPP changes). Consequently, as proposed in H5, particularly for peatlands, it is of fundamental importance to consider variations in MAP as well as MAT in future climate models of Cstock and C-flux changes. Importantly, the C-stocks in peat columns reflect a SOM quality mixture, not a time-rate-dependent (inert) C-pool (as, for example, that assumed in the RothC model); thus, they are susceptible to environmental change (i.e. WTD). However, total C-losses were limited by the peat's hydrological resilience, although there is a large potential for $\mathrm{CH}_{4}$ production under greater WTD, a factor of marked importance when considering management strategies for peat restoration projects (Holden et al. 2003, Baird et al. 2009). 


\subsection{Sensitivity analysis}

Apart from MAP (Fig. 6), the most important of the factors considered here determining peat accumulation (see Figs. 7 \& 8) were runoff, affecting WTD; litter quality (i.e. lignin), affecting decomposition rates; and $\mathrm{BD}$, affecting WTD and consequently PFT, litter input and decomposition rates and, thus, long-term Caccumulation (e.g. lower surface BD causes burial of litter/SOM below the WTD, and thus peat accumulation occurs more quickly). Although increasing amounts of peatland litter quality data have become available (e.g. Moore et al. 2007), they often do not relate to model requirements (e.g. not adding up to $100 \%$, no long-term incubations, no proportional decomposition rates, e.g. lignin). However, BD profiles are known to vary between regions, likely due to PFT-specific litter BD and SOM compaction potential. Clearly more detailed sitespecific BD profile data from different peatland regions are needed, as even slight changes in BD result in large model effects on SOC stocks and peat depth (Fig. 8A).

\subsection{Model limitations and future developments}

\subsubsection{MILLENNIA peat cohort model}

Although our MILLENNIA PDM performed well for our site (Figs. 4 \& 5) and, importantly, accurately predicted changes in total SOC stocks and peat depth across a catchment area with variable slope and aspect (Table 3), it only models peat (and not mineral or organo-mineral soils) and relies on a simple hydrology concept (point model), not including spatial water flow. It could be improved by considering peat growth effects and lateral water flow (see Belyea \& Baird 2006). It also does not include water chemistry (i.e. the redox potential and $\mathrm{pH}$ ). Furthermore, we still lack a robust reconstruction of Holocene climate, as well as sitespecific NPP and litter quality; the parameters in Table 2 could certainly be further developed based on emerging literature. Moreover, wider application of the model might require more complex soil temperature calculations, PFT response surfaces (e.g. temperature) and different PFT litter BDs to extend it to tropical or permafrost regions. The export of DOC is empirical and does not consider temperature effects and interactions with the nitrogen cycle are not represented; thus, no litter N-limitations on NPP can be modelled. We envisage the addition of such structures to extend this model to other sites and biomes, and a clear advantage of the MILLENNIA PDM is its simple structure, allowing easy addition of other modules. Another advantage is the relation to measurable data inputs and the capability of obtaining field depth-age validation data of litter qual- ity and SOM 'proportional bin' components and their turnover rates, a constraint in conventional SOM pool models (Feng 2009). Another prospect is to use the continuous-quality model approach for litter decomposition (Bosatta \& Ågren 2003), including SOM quality information from near-infrared spectra, for example.

\subsubsection{Including MILLENNIA cohort concept into other models}

In light of our findings, we propose to combine this cohort-based approach with other current mineral soil concepts, such as the CENTURY model, which seems suitable for peatland SOM turnover (Chimner et al. 2002). The aim would be to create a model continuum of mineral to organo-mineral to peat, including soil mixing. This would be aimed at overcoming some of the current fundamental global model limitations of not representing organic-rich and cohort-layered peat soils with high dynamic WTDs and consequent $\mathrm{CH}_{4}$ fluxes. This effort will benefit from the scientific knowledge on pedogenesis (e.g. Jenny 1941, Ponge 2003, Baumann et al. 2009), including mainly climate, soil and litter $\mathrm{pH}$ effects on soil biota (key species) and, consequently, on litter decomposition, leading to organic-layer (e.g. humus) and, potentially, peat formation. Unlike existing model concepts, which propose static soil and hydrological properties, soil layers would develop through time (in relation to ground water or WTD), and, consequently, edaphic properties would be represented dynamically via biological, physical and chemical activity; such considerations could eliminate the shortfalls highlighted by Trettin et al. (2001) in 12 major models. For example, the BD (and thus pore space and water holding capacity) would vary as the organic and mineral fractions change over time through SOM input and mixing (i.e. bioturbation or cryoturbation); notably, for peat layers, there would be no texture proportion included. Recently, there have been attempts to include simple advective SOM transport into SOM models (Jenkinson \& Coleman 2008). This appears to be a promising way to achieve litter and humus horizon representation in model structures and, thus, inclusion of the universal role of soil biota on C-stocks and turnover, as recognised by Bardgett et al. (2009), which is reflected in humus forms representing ecosystem strategies for nutrient and C-cycling (Ponge 2003). Changing WTD dynamics then affects the SOM decomposition pathways, potentially leading to peat formation and resulting C-fluxes (i.e. $\mathrm{CO}_{2}$ and $\mathrm{CH}_{4}$ ). Anaerobic decomposition could be based on calculated and field-measurable changes in redox potential (Eh) as in the DeNitrification-DeComposition (DNDC) model (Zhang et al. 2002). 


\section{CONCLUSIONS}

The MILLENNIA PDM cohort model realistically predicted peat accumulation based on basic model drivers and processes, with inclusion of a dynamic WTD, PFT changes and peat cohort age information. Model runs showed WTD (i.e. MAP and runoff), bulk density and decomposition rates (including litter quality) to be the most influential factors determining peat accumulation. Other parameters such as root distribution and root litter input were less important. Whereas, presently, most models pay particular attention to elevated MAT (i.e. affecting decomposition), in the MILLENNIA model, MAT is of less importance, mainly affecting peat growth through NPP. Simulations of future climate showed MAP to be of much greater significance in regulating total peat column $\mathrm{C}$ gains or losses and $\mathrm{C}$ emissions (i.e. $\mathrm{CH}_{4}$ ) through WTD changes, thus underlining the interlinked role of peatland $\mathrm{C}$ and the water cycle, which play an important role in determining the UK's C budget, with implications for land management (e.g. drainage). However, including dynamic peat depth and WTD in the model is a prerequisite for predicting realistic soil carbon stock changes. At the catchment scale, DEM dependent runoff and erosion were important factors, leading to shallow peats around steep, south-facing slopes. In addition, field data are needed, particularly for erosion, decomposition-only fluxes, including $\mathrm{CH}_{4}$ ebullition, improved PMT process understanding and overall aspect and slope effects on climate and WTD.

Moreover, there is a clear need for a novel approach to simulate SOC accumulation across a mineral to organo-mineral to peat continuum, particularly considering vertical stratification of soils with SOM pools based not on age, but on pedogenesis processes. In this attempt the inclusion of dynamic hydrology, due to changes in SOM input and incorporation in the mineral soil matrix as a result of soil mixing, is vital. A combination of the conventional 'CENTURY-type' approach for mineral soils and the 'cohort-based' litter cohort approach used for peat modelling appears promising for the development of a more realistic model of SOM pools across dynamic soil horizons and with layered $\mathrm{C}$-age information.

Acknowledgements. We thank Anna Clark and Trevor Keenan for their initial model contributions as part of a NERC-funded student project. We are grateful to the ECN data manager (www.ecn.ac.uk/) for granting access to Moor House climatic and soil data and EDINA (UK, Crown Copyright/database right 2009) for providing DEM data. The award of a Philip Leverhulme Prize to Joseph Holden is acknowledged allowing him time to contribute to the writing of this manuscript. Simon Croft was funded by a NERC Masters studentship and a NERCfunded initiative (UKPopNet). We thank 2 anonymous reviewers for their helpful comments and suggestions.

\section{LITERATURE CITED}

Adair EC, Parton WJ, Del Grosso SJ, Silver WL and others (2008) Simple three-pool model accurately describes patterns of long-term litter decomposition in diverse climates. Glob Change Biol 14:2636-2660

Baird AJ, Holden J, Chapman PJ (2009) A literature review of evidence of methane emissions from peatlands. Report SP0572, Defra, London

Bardgett RD, De Deyn GB, Ostle NJ (2009) Plant-soil interactions and the carbon cycle. J Ecol 97:838-839

Barry RG, Chorley RJ (eds) (2003) Atmosphere, weather, and climate. Social science, 8th edn. Routledge, London

Bauer IE (2004) Modelling effects of litter quality and environment on peat accumulation over different time-scales. J Ecol 92:661-674

Bauer IE, Gignac LD, Vitt DH (2003) Development of a peatland complex in boreal western Canada: lateral site expansion and local variability in vegetation succession and long-term peat accumulation. Can J Bot 81:833-847

Baumann F, He JS, Schmidt K, Kuhn P, Scholten T (2009) Pedogenesis, permafrost, and soil moisture as controlling factors for soil nitrogen and carbon contents across the Tibetan Plateau. Glob Change Biol 15:3001-3017

Belyea LR, Baird AJ (2006) Beyond 'the limits to peat bog growth': cross-scale feedback in peatland development. Ecol Monogr 76:299-322

Berg B (1986) Nutrient release from litter and humus in coniferous forest soils - a mini review. Scand J For Res 1: 359-369

Berg B, Ekbohm G (1991) Litter mass loss rates and decomposition patterns in some needle and leaf litter types. Longterm decomposition in a Scots pine forest. VII. Can J Bot 69:1449-1456

Berg B, McClaugherty C (eds) (2003) Plant litter, decomposition, humus formation and carbon sequestration. Springer Verlag, Heidelberg

Billett MF, Palmer SM, Hope D, Deacon C and others (2004) Linking land-atmosphere-stream carbon fluxes in a lowland peatland system. Global Biogeochem Cycles 18: GB1024. doi:10.1029/2003GB002058

Bol RA, Harkness DD, Huang Y, Howard DM (1999) The influence of soil processes on carbon isotope distribution and turnover in the British uplands. Eur J Soil Sci 50:41-51

Bolin B, Sukumar R, Ciais P, Cramer W and others (2001) The global perspective. In: Watson RT, Noble IR, Bolin B, Ravindranath NH, Verardo DJ, Dokken DJ (eds) IPCC special report on land use, land-use change and forestry. Cambridge University Press, Cambridge, p 23-51

> Bosatta E, Ågren GI (2003) Exact solutions to the continuousquality equation for soil organic matter turnover. J Theor Biol 224:97-105

Bunbury J, Viau A, Gajewski K, Peros M (2006) Regional climate change in northern North America during the Holocene. Poster abstract 2006AGUFM.A53E0245B American Geophysical Union Meeting, December 11-15, San Francisco, CA

Canadell JG, Ciais P, Dhakal S, Le Quéré C, Patwardhan A, Raupach MR (2009) UNESCO-SCOPE-UNEP Policy Briefs Series. The global carbon cycle-2 November 2009. UNESCO-SCOPE-UNEP, Paris

> Charman DJ, Hendon D (2000) Long-term changes in soil water tables over the past 4500 years: relationships with climate and North Atlantic atmospheric circulation and sea surface temperature. Clim Change 47:45-59

Chimner RA, Cooper DJ, Parton WJ (2002) Modeling carbon accumulation in rocky mountain fens. Wetlands 22: $100-110$ 
Clark JM, Billett MF, Coyle M, Croft S and others (2010) Model inter-comparison between statistical and dynamic model assessments of the long-term stability of blanket peat in Great Britain (1940-2099). Clim Res 45:227-248

Clymo RS (1984) The limits to peat bog growth. Philos Trans R Soc Lond B 303:605-654

- Clymo RS, Turunen J, Tolonen K (1998) Carbon accumulation in peatland. Oikos 81:368-388

> Cox PM, Betts RA, Jones CD, Spall SA, Totterdell IJ (2000) Acceleration of global warming due to carbon cycle feedbacks in a coupled climate model. Nature 408:184-187

Evans MG, Burt TP, Holden J, Adamson JK (1999) Runoff generation and water table fluctuations in blanket peat: evidence from UK data spanning the dry summer of 1995. J Hydrol (Amst) 221:141-160

Feng Y (2009) Fundamental considerations of soil organic carbon dynamics: a new theoretical framework. Soil Sci 174: 467-481 doi:10.1097/SS.0b013e3181bb0e87

Forrest GI (1971) Structure and production of North Pennine blanket bog vegetation. J Ecol 59:453-479

Friedlingstein P, Cox P, Betts R, Bopp L and others (2006) Climate-Carbon cycle feedback analysis: results from the C4MIP model intercomparison. J Clim 19:3337-3353

Frolking S, Roulet NT, Moore TR, Richard PJH, Lavoie M, Muller SD (2001) Modeling northern peatland decomposition and peat accumulation. Ecosystems 4:479-498

Gajewski K, Viau A, Sawada M, Atkinson D, Fines P (2004) Synchronicity of Holocene climate changes in Europe and North America. Poster abstract 2004AGUSMGC41A.08G American Geophysical Union/Canadian Geophysical Union Ann Meet, Montreal, Québec

Garnett MH (1998) Carbon storage in Pennine moorland and response to change. $\mathrm{PhD}$ dissertation, Department of Geography, University of Newcastle-Upon-Tyne

- Garnett MH, Hardie SML (2009) Isotope $\left({ }^{14} \mathrm{C}\right.$ and $\left.{ }^{13} \mathrm{C}\right)$ analysis of deep peat $\mathrm{CO}_{2}$ using a passive sampling technique. Soil Biol Biochem 41:2477-2483

Garnett MH, Ineson P, Stevenson AC, Howard DC (2001) Terrestrial organic carbon storage in a British moorland. Glob Change Biol 7:375-388

Gholz HL, Wedin DA, Smitherman SM, Harmon ME, Parton WJ (2000) Long-term dynamics of pine and hardwood litter in contrasting environments: toward a global model of decomposition. Glob Change Biol 6:751-765

Gignac LD, Vitt DH, Bayley SE (1991) Bryophyte response surfaces along ecological and climatic gradients. Vegetatio 93:29-45

> Goidts E, Wesemael B, Van Oost K (2009) Driving forces of soil organic carbon evolution at the landscape and regional scale using data from a stratified soil monitoring. Glob Change Biol 15:2981-3000

Gorham E (1991) Northern peatlands. Role in the carbon cycle and probable responses to climatic warming. Ecological Applications 1:182-195

Hardie SML, Garnett MH, Fallick AE, Ostle NJ, Rowland AP (2009) Bomb ${ }^{14} \mathrm{C}$ analysis of ecosystem respiration reveals that peatland vegetation facilitates release of old carbon. Geoderma 153:393-401

Heal OV, Smith RAH (1978) Introduction and site description. In: Heal OW, Perkins DF (eds) Production ecology of British moors and montane grasslands. Springer, Berlin, p 3-16

Heal OV, Latter PM, Howson G (1978) A study of rates of decomposition of organic matter. In: Heal OW, Perkins DF (eds) Production ecology of British moors and montane grasslands. Springer, Berlin, p 136-159

Holden J (2005) Peatland hydrology and carbon release: why small-scale process matters. Philos Trans R Soc, A 363:
2891-2913

Holden J, Burt TP (2002) Infiltration, runoff and sediment production in blanket peat catchments: implications of field rainfall simulation experiments. Hydrol Process 16: 2537-2557

Holden J, Rose R (2010) Temperature and surface lapse rate change: a study of the UK's longest upland instrumental record. Int J Climatol. doi:10.1002/joc.2136

> Holden J, Burt TP, Vilas M (2002) Application of ground penetrating radar to the identification of subsurface piping in blanket peat. Earth Surf Process Landf 27:235-249

Holden J, Shotbolt L, Bonn A, Burt TP and others (2007) Environmental change in moorland landscapes. Earth Sci Rev 82:75-100

Huang Y, Li B, Bryant C, Bol R, Eglinton G (1999) Radiocarbon dating of aliphatic hydrocarbons: a new approach for dating passive-fraction carbon in soil horizons. Soil Sci Soc Am J 63:1181-1187

Ingram HAP (1982) Size and shape in raised mire ecosystems: a geophysical model. Nature 297:300-303

IPCC (Intergovernmental Panel on Climate Change) (1990) Climate change: The IPCC scientific assessment. Cambridge University Press, Cambridge

IPCC (2007) Climate change: The physical science basis. Contribution of Working Group I to the 4th Assessment Report of the IPCC. Cambridge University Press, Cambridge

Ise T, Dunn AL, Wofsy SC, Moorcroft PR (2008) High sensitivity of peat decomposition to climate change through water-table feedback. Nat Geosci 1:763-766

ISLSCP II (International Satellite Land Surface Climatology Project) (2005) Global gridded surfaces of selected soil characteristics for the International Satellite Land Surface Climatology Project (ISLSCP) Initiative. II. Data collection. DVD/CD-ROM. NASA, 2005

Jenkinson DS, Coleman K (2008) The turnover of organic carbon in subsoils. 2. Modelling carbon turnover. Eur J Soil Sci 59:400-413

Jenkinson DS, Hart PBS, Rayner JH, Parry LC (1987) Modelling the turnover of organic matter in long-term experiments at Rothamsted. INTECOL Bull 15:1-8

Jenny H (1941) Factors of soil formation. A system of quantitative pedology. McGraw-Hill Book, New York, NY

> Jenny H, Gessel S, Bingham FT (1949) Comparative study of decomposition rates of organic matter in temperate and tropical regions. Soil Sci 68:419-432

Johnson GAL, Dunham KC (1963) The geology of Moor House. Nature Conservancy Monograph 2, HMSO, London

Jones HE, Gore AJP (1978) A simulation of production and decay in blanket bog. In: Heal OW, Perkins DF (eds) Production ecology of British moors and montane grasslands. Springer, Berlin, p 160-186

Jones MC, Yu Z (2010) Rapid deglacial and early Holocene expansion of peatlands in Alaska. Proc Natl Acad Sci USA 107:7347-7352

Jones C, McConnell C, Coleman K, Cox P, Falloon P, Jenkinson D, Powlson D (2004) Global climate change and soil carbon stocks; predictions from two contrasting models for the turnover of organic carbon in soil. Glob Change Biol 10:1-13

Jungkunst HF, Fiedler S (2007) Latitudinal differentiated water table control of carbon dioxide, methane and nitrous oxide fluxes from hydromorphic soils: feedbacks to climate change. Glob Change Biol 13:2668-2683

Kelly RH, Parton WJ, Crocker GJ, Graced PR and others (1997) Simulating trends in soil organic carbon in longterm experiments using the century model. Geoderma 81: 75-90 
Kosykh NP, Koronatova NG, Naumova NB, Titlyanova AA (2008) Above- and below-ground phytomass and net primary production in boreal mire ecosystems of western Siberia. Wetlands Ecol Manag 16:139-153

Laine A, Wilson D, Kiely G, Byrne KA (2007) Methane flux dynamics in an Irish lowland blanket bog. Plant Soil 299: 181-193

Leemans R (1992) Global Holdridge life zone classifications. Digital raster data on a 0.5-degree Cartesian orthonormal geodetic (lat/long) $360 \times 720$ grid. In: Global ecosystems database Version 2.0. Two independent single-attribute spatial layers. 537, 430 bytes in 8 files, NOAA National Geophysical Data Center, Boulder, CO (first published in 1989)

Le Quéré C, Raupach MR, Canadell JG, Marland G and others (2009) Trends in the sources and sinks of carbon dioxide. Nat Geosci 2:831-836

Lieth H, Box E (1972) Evapotranspiration and primary productivity: Thornthwaite Memorial Model. Publ Climatol 25:37-46

> Limpens J, Berendse F, Blodau C, Canadell JG and others (2008) Peatlands and the carbon cycle: from local processes to global implications - a synthesis. Biogeosciences 5:1475-1491

> Luyssaert S, Schulze ED, Börner A, Knohl A and others (2008) Old-growth forests as global carbon sinks. Nature 455: 213-215

Meentemeyer V (1978) Macroclimate and lignin control of litter decomposition rates. Ecology 59:465-472

Minderman G (1968) Addition, decomposition and accumulation of organic matter in forests. J Ecol 56:355-362

> Moore TR, Bubier JL, Bledzki L (2007) Litter decomposition in temperate peatland ecosystems: the effect of substrate and site. Ecosystems 10:949-963

Parton WJ, Schimel DS, Cole CV, Ojima DS (1987) Analysis of factors controlling soil organic matter levels in Great Plain grasslands. Soil Sci Am J 51:1173-1179

Ponge JF (2003) Humus forms in terrestrial ecosystems: a framework to biodiversity. Soil Biol Biochem 35:935-945

Potter CS (1997) An ecosystem simulation model for methane production and emission from wetlands. Global Biogeochem Cycles 11:495-506

Rodeghiero M, Heinemeyer A, Schrumpf M, Bellamy P (2009) Determination of changes in soil carbon stocks. In: Kutsch W, Bahn M, Heinemeyer A (eds) Soil carbon dynamics: an integrated methodology. Cambridge University Press, Cambridge, p 49-75

Schimel J (1995) Plant transport and methane production as controls on methane flux from Arctic wet meadow tundra. Biogeochemistry 28:183-200

Sebacher D, Harriss R, Bartlett K (1985) Methane emissions to the atmosphere through aquatic plants. J Environ Qual 14: $40-46$

Tallis JH (1991) Forest and moorland in the south Pennine uplands in the mid-Flandrian period. III. The spread of moorland-local regional and national. J Ecol 79:401-415

Tarnocai C, Canadell JG, Schuur EAG, Kuhry P, Mazhitova G, Zimov S (2009) Soil organic carbon pools in the northern circumpolar permafrost region. Global Biogeochem Cycles 23:GB2023. doi:10.1029/2008GB003327

Trettin CC, Song B, Jurgensen MF, Li C (2001) Existing soil carbon models do not apply to forested wetlands. Gen
Tech Rep SRS-46, US Department of Agriculture, Forest Service, Southern Research Station, Asheville, NC

Turc L (1954) The water balance of soils, relation between precipitation evapotranspiration and runoff. Annales Agronomique 5:491-595

Wallman P, Belyazid S, Sveensson MGE, Svedrup H (2006) DECOMP - a semi-mechanistic model of litter decomposition. Environ Model Softw 21:33-44

- Wania R, Ross I, Prentice IC (2009a) Integrating peatlands and permafrost into a dynamic global vegetation model. 1. Evaluation and sensitivity of physical land surface processes. Global Biogeochem Cycles 23:GB3014. doi:10.1029/ 2008GB003412

Wania R, Ross I, Prentice IC (2009b) Integrating peatlands and permafrost into a dynamic global vegetation model. 2 . Evaluation and sensitivity of vegetation and carbon cycle processes. Global Biogeochem Cycles 23:GB3015. doi: 10.1029/2008GB003413

Ward SE, Bardgett RD, McNamara NP, Adamson JK, Ostle NJ (2007) Long-term consequences of grazing and burning on northern peatland carbon dynamics. Ecosystems 10: 1069-1083

- Watson A, Stephen KD, Nedwell DB, Arah JRM (1997) Oxidation of methane in peat: kinetics of $\mathrm{CH}_{4}$ and $\mathrm{O}_{2}$ removal and the role of plant roots. Soil Biol Biochem 29:1257-1267

Webb W, Szarek S, Lauenroth W, Kinerson R and others (1978) Primary productivity and water use in native forest, grassland, and desert ecosystems. Ecology 59:1239-1247

Woodward FI, Lomas MR, Betts RA (1998) Vegetationclimate feedbacks in a greenhouse world. Philos Trans R Soc B 353:29-38

Worrall F, Reed M, Warburton J, Burt T (2003) Carbon budget for a British upland peat catchment. Sci Total Environ 312:133-146

Xu Q, Xiao J, Li Y, Tian F, Nakagawa T (2009) Pollen-based quantitative reconstruction of Holocene climate changes in the Daihai Lake area, Inner Mongolia, China. J Clim 23:2856-2868

Yu Z, Campbell ID, Vitt DH, Apps MJ (2001a) Modelling long-term peatland dynamics. I. Concepts, review, and proposed design. Ecol Model 145:197-210

Yu Z, Campbell ID, Vitt DH, Apps MJ (2001b) Modelling long-term peatland dynamics. II. Processes and rates as inferred from litter and peat-core data. Ecol Model 145: 159-173

Yu Z, Campbell ID, Campbell C, Vitt DH, Bond GC, Apps MJ (2003) Carbon sequestration in western Canadian peat highly sensitive to Holocene wet-dry climate cycles at millennial timescales. Holocene 13:801-808

Zhang Y, Li C, Trettin CC, Li H, Sun G (2002) An integrated model of soil, hydrology, and vegetation for carbon dynamics in wetland ecosystems. Global Biogeochem Cycles 16:1061-1078

Zhou G, Guan L, Wei X, Tang X and others (2008) Factors influencing leaf litter decomposition: an intersite decomposition experiment across China. Plant Soil 311:61-72

Zoltai SC, Siltanen RM, Johnson RD (2000) A wetland database for the western boreal, subarctic and arctic regions of Canada. Information report NORX-368, Natural Resources Canada, Canadian Forestry Service, Northern Forestry Centre, Edmonton

Proofs received from author(s): December 9, 2010 